\title{
WestVirginiaUniversity
}

THE RESEARCH REPOSITORY @ WVU

Graduate Theses, Dissertations, and Problem Reports

2010

\section{An Exploration of the Spatial Distribution of National Park Units}

Daniel Servian

West Virginia University

Follow this and additional works at: https://researchrepository.wvu.edu/etd

\section{Recommended Citation}

Servian, Daniel, "An Exploration of the Spatial Distribution of National Park Units" (2010). Graduate

Theses, Dissertations, and Problem Reports. 3067.

https://researchrepository.wvu.edu/etd/3067

This Thesis is protected by copyright and/or related rights. It has been brought to you by the The Research Repository @ WVU with permission from the rights-holder(s). You are free to use this Thesis in any way that is permitted by the copyright and related rights legislation that applies to your use. For other uses you must obtain permission from the rights-holder(s) directly, unless additional rights are indicated by a Creative Commons license in the record and/ or on the work itself. This Thesis has been accepted for inclusion in WVU Graduate Theses, Dissertations, and Problem Reports collection by an authorized administrator of The Research Repository @ WVU. For more information, please contact researchrepository@mail.wvu.edu. 
An Exploration of the Spatial Distribution of National Park Units

Daniel Servian

Thesis submitted to the

Davis College of Agriculture, Natural Resources \& Design

at West Virginia University

in partial fulfillment of the requirements

for the degree of

Master of Science

in

Recreation, Parks, and Tourism Resources

Jinyang Deng, Ph.D., Chair

David Smaldone, Ph.D.

Michael Strager, Ph.D.

Recreation, Parks, and Tourism Resources Program

Division of Forestry and Natural Resources

Morgantown, West Virginia

2010

Keywords: National Park, Designation, Distribution, Spatial, Exploratory Data Analysis, Exploratory Spatial Data Analysis, Cluster, Politics, Partisanship, History, Geography

Copyright 2010 Daniel Servian 


\section{ABSTRACT \\ An Exploration of the Spatial Distribution of National Park Units}

\section{Daniel Servian}

National Parks can reveal a glimpse into significant aspects of a culture. Visiting and experiencing a National Park can open a window into a culture's heritage, intellectual philosophy, triumphs, and sorrows. As of 2009, the National Park Service administered 393 National Park units, located across America and its territories. The purpose of this paper is to spatially investigate the National Park designation process. Examination of the trends and patterns within the National Park designation process required computation of the data via exploratory data analysis (EDA) and exploratory spatial data analysis (ESDA). This analysis will illustrate significant clusters and correlation between the location of a National Park unit and three overriding themes being; historical, political, and geographical in nature. Furthermore, the results show significant partisanship between the two major political affiliations, when making decisions regarding National Park unit designations. Additionally, it will be shown that political affiliation can be predicted from the type of National Park unit designation. 
Table of Contents

ABSTRACT

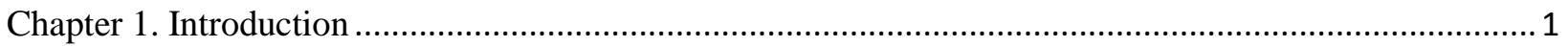

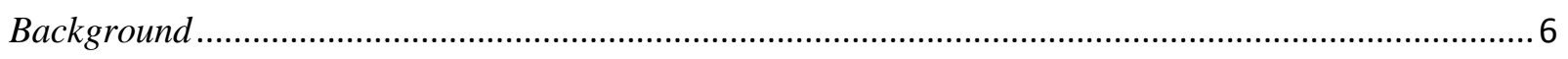

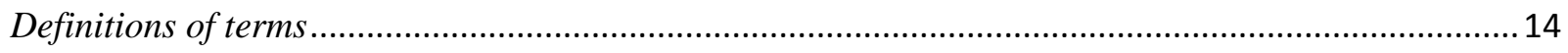

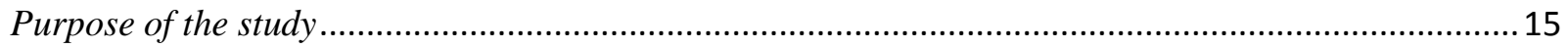

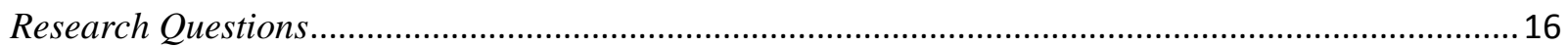

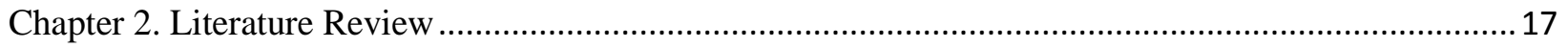

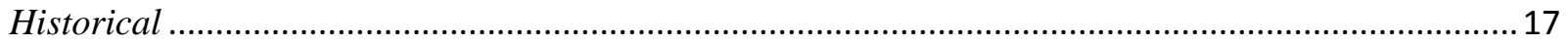

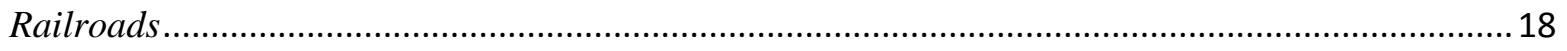

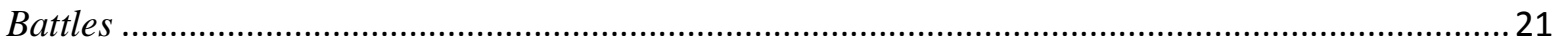

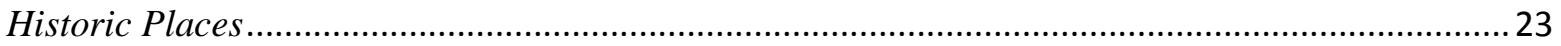

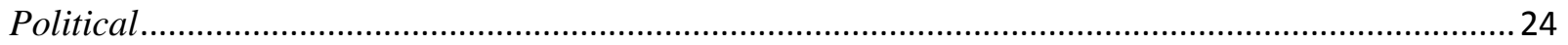

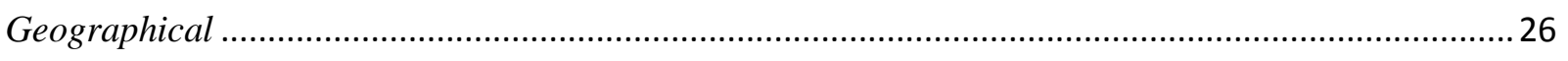

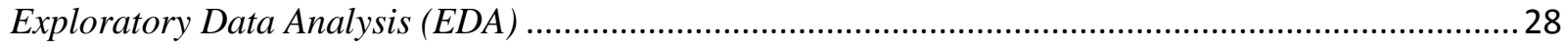

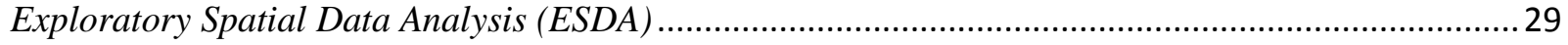

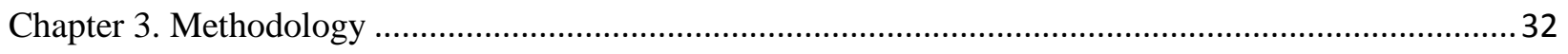

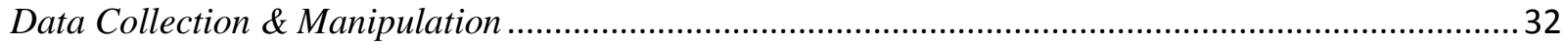

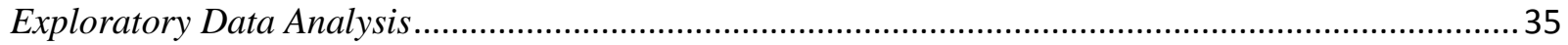

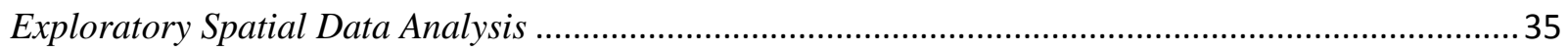

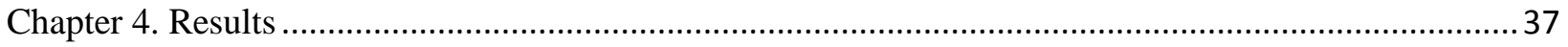

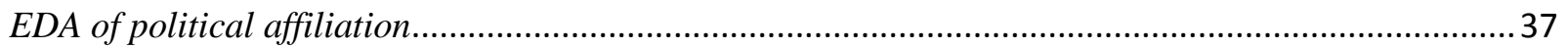

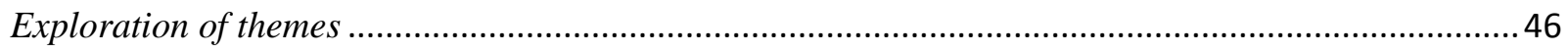




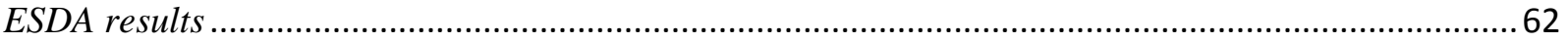

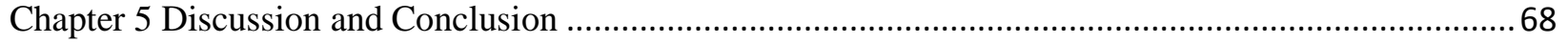

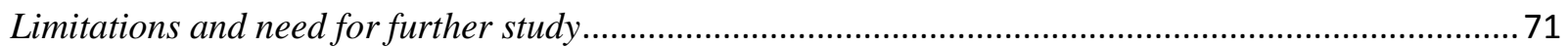

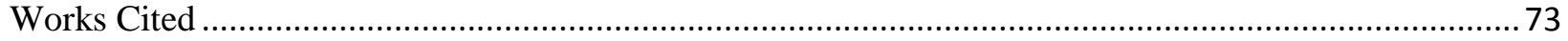


List of Tables

Page 2 ...........Table 1. The number of designations per designation heading in this study

Page 3 ...........Table 2. National Park designation types with definitions

Page 13 ...........Table 3. Simplified National Park designation process

Page 20 ............Table 4. Major wars on U.S. soil

Page 36 ...........Table 5. Theme spatial representation 


\section{List of Graphs}

Page 37 ...........Graph 1. Observing the designations in terms of acreage by the political affiliation of the President and Congress (A)

Page 38 ........... Graph 2. Observing the designations in terms of acreage by the political affiliation of the President and Congress (B)

Page 38...........Graph 3. Observing the designations in terms of acreage by the political affiliation of the President and Congress $(\mathrm{C})$

Page 39...........Graph 4. Observing the designations in terms of acreage by the political affiliation of the President and Congress (D)

Page $39 . . . . . . . . .$. Graph 5. Observing the designations in terms of acreage by the political affiliation of the President and Congress (E)

Page 41..........Graph 6. 22 Historical designations

Page 42 ...........Graph 7. Majority National Monuments and National Parks

Page 42 ...........Graph 8. Near normal distribution

Page 43........... Graph 9. Pie chart of presidential designations for all National Park units

Page 44........... Graph 10. Pie Chart of the political affiliation of the congress

Page 45...........Graph 11. Time line of all designation

Page 46...........Graph 12. Time line of designation between $1872-1922$ in the west

Page 47 .......... Graph 13. Pie chart of designation between the years of $1872-1922$ in the west

Page 48...........Graph 14. Matrix plot of cooperation between Congress and the President between the years of 1872 - 1922 in the west with parks that correlate with the railroad land grants

Page 49 ............Graph 15. A regression for predicting the president's political affiliation via the congress political affiliation from all data (1872 - 2007).

Page 50 ...........Graph 16. A regression for predicting the congress political affiliation from the designated National Park’s simplified designation from all data (1872 - 2007).

Page 63 ...........Graph 17. Moran’s I with P-Value for 2007 population

Page 66........... Graph 18. Moran’s I with P-Value for simple designation description

Page 67 ...........Graph 19. Getis-Ord G of National Park Simple designation description 


\section{List of Maps}

Page 8 ............Map 1. Northern Pacific RR land grant near Yellowstone

Page 9 ............Map 2. National Park units between 1872 - 1916

Page 21...........Map 3. Railroad resorts

Page 52........... Map 4. The distribution of all National Park units from (1872 - 2007).

Page 53............Map 5. Shows the correlation between the railroad land grants and the formation of National Park units.

Page 54........... Map 6. Western National Park units pre 1923 with railroad land grants

Page 55............Map 7. The National Park units pre 1923 in the west the reside within the land grants of the railroads

Page 56............Map 8. National Park units that intersect the railroad land grant with a 100 mile buffer

Page 57............Map 9. The association between major battles fought on United States soil and the number of military designated National Park units

Page 58............Map 11. National Park units that intersect streams or shore

Page 60........... Map 12. National Park units that associate with Federal Lands

Page 61........... Map 13. National Park units associated with all variables

Page 62............Map 14. Univariate LISA 2007 Population

Page 65............Map 15. A LISA analysis of the simple designation description 
List of Graphics

Page 20...........Graphic 1. Railroad advertising

Page 20...........Graphic 2. Lewis Glacier Lodge

Page 34...........Graphic 3. Federal county ID 
Chapter 1. Introduction

The parks do not belong to one state or to one section [....] The Yosemite, the Yellowstone, the Grand Canyon are national properties in which every citizen has a vested interest; they belong as much to the man of Massachusetts, of Michigan, of Florida, as they do to the people of California, of Wyoming, and of Arizona. (Stephen T. Mather, NPS Director, 1917-1929)

One of the best ways to learn about a region's people is to see what its citizens have protected and preserved (National Park Service, 2003). Experiencing natural and historically significant aspects of an area can open a window into a culture’s: heritage, intellectual philosophy, triumphs, and sorrow (Yard, 1922). Protection and preservation of resources assure that future generations will enjoy and more importantly learn about their ancestors’ experiences. Every generation attempts to leave their legacy for future generations. One way of preserving the past is by designating a National Park. The creation of a National Park will leave that generation’s mark on time revealing a glimpse into their morals and values.

Preservation is not a small undertaking; it takes extensive planning, vast economic resources, and most importantly agreement in the significance of the resource (National Park Service, 2003). As of 2009, there were 393 National Park units spread throughout America and its territories. National Park units are structured into one of 39 specific designations, such as National Historic site, National Lakeshore, and National Recreation Area (Table 1). These designations are categorized into one of 16 designation types by the United States Congress (Table 2). 
Table 1. The number of designations per designation heading in this study

\begin{tabular}{|lc|lc|}
\hline Designation title & $\begin{array}{c}\text { Total per } \\
\text { designation }\end{array}$ & Designation title & $\begin{array}{c}\text { Total per } \\
\text { designation }\end{array}$ \\
\hline Ecological and Historical Preserve & 1 & National Mall & 3 \\
\hline Historical Park & 1 & National Memorial & 19 \\
\hline International Historic Site & 1 & National Memorial* & 1 \\
\hline International Peace Memorial & 1 & National Military Park & 9 \\
\hline Memorial Parkway & 2 & National Monument & 69 \\
\hline National Battlefield & 10 & $\begin{array}{l}\text { National Monument and Historic } \\
\text { Shrine }\end{array}$ & 1 \\
\hline National Battlefield Park & 1 & National Park & 42 \\
\hline National Battlefield Park* & 2 & National Park* & 5 \\
\hline National Battlefield Site & 1 & National Preserve & 5 \\
\hline National Battlefield* & 2 & National Recreation Area & 18 \\
\hline National Heritage Corridor & 1 & National Recreation Area* & 1 \\
\hline National Historic Landmark District & 1 & National Recreation River & 1 \\
\hline National Historic Park & 3 & National Reserve & 2 \\
\hline National Historic Park* & 2 & National River & 2 \\
\hline National Historic Site & 71 & National River and Recreation Area & 3 \\
\hline National Historic Site* & 2 & National Scenic River & 1 \\
\hline National Historic Trail & 1 & National Scenic River way & 2 \\
\hline National Historical Park & 26 & National Scenic Trail & 10 \\
\hline National Historical Park and & 1 & National Seashore & 1 \\
\hline Preserve* & & & 11 \\
\hline National Historical Park* & 4 & National Wild and Scenic River & 1 \\
\hline National Historical Reserve & 1 & Park & 1 \\
\hline National Historical Site & 4 & Parkway & Scenic and Recreational River \\
\hline National Lakeshore & 4 & Wild and Scenic River & 1 \\
\hline & & & \\
\hline Source The a & & & 1 \\
\hline
\end{tabular}

Source: The author

* Indicates National Park units that have changed designation titles to the new designation 
Table 2. National Park designation types with definitions (National Park Service, 2000)

\begin{tabular}{|c|c|}
\hline Designation Type & Overview \\
\hline National Park & $\begin{array}{l}\text { These are generally large natural places having } \\
\text { a wide variety of attributes, at times including } \\
\text { significant historic assets. Hunting, mining and } \\
\text { consumptive activities are not authorized. }\end{array}$ \\
\hline National Monument & $\begin{array}{l}\text { The Antiquities Act of } 1906 \text { authorized the } \\
\text { President to declare by public proclamation } \\
\text { landmarks, structures, and other objects of } \\
\text { historic or scientific interest situated on lands } \\
\text { owned or controlled by the government to be } \\
\text { national monuments. }\end{array}$ \\
\hline National Preserve & $\begin{array}{l}\text { National preserves are areas having } \\
\text { characteristics associated with national parks, } \\
\text { but in which Congress has permitted continued } \\
\text { public hunting, trapping, oil/gas exploration } \\
\text { and extraction. Many existing national } \\
\text { preserves, without sport hunting, would qualify } \\
\text { for national park designation }\end{array}$ \\
\hline National Historic Park & $\begin{array}{l}\text { Usually, a national historic site contains a } \\
\text { single historical feature that was directly } \\
\text { associated with its subject. Derived from the } \\
\text { Historic Sites Act of 1935, a number of historic } \\
\text { sites were established by secretaries of the } \\
\text { Interior, but most have been authorized by acts } \\
\text { of Congress. }\end{array}$ \\
\hline National Historical Park & $\begin{array}{l}\text { This designation generally applies to historic } \\
\text { parks that extend beyond single properties or } \\
\text { buildings. }\end{array}$ \\
\hline National Memorial & $\begin{array}{l}\text { A national memorial is commemorative of a } \\
\text { historic person or episode; it need not occupy a } \\
\text { site historically connected with its subject. }\end{array}$ \\
\hline National Battlefield & $\begin{array}{l}\text { This general title includes national battlefield, } \\
\text { national battlefield park, national battlefield } \\
\text { site, and national military park. In 1958, an } \\
\text { NPS committee recommended national } \\
\text { battlefield as the single title for all such park } \\
\text { lands. }\end{array}$ \\
\hline National Cemetery & $\begin{array}{l}\text { There are presently } 14 \text { national cemeteries in } \\
\text { the National Park System, all of which are } \\
\text { administered in conjunction with an associated } \\
\text { unit and are not accounted for separately. }\end{array}$ \\
\hline
\end{tabular}




\begin{tabular}{|l|l|}
\hline Twelve NRAs in the system are centered on \\
large reservoirs and emphasize water-based \\
recreation. Five other NRAs are located near \\
major population centers. Such urban parks \\
combine scarce open spaces with the \\
preservation of significant historic resources \\
and important natural areas in location that can \\
provide outdoor recreation for large numbers \\
of people.
\end{tabular}


Places of profound national importance, as with Gettysburg National Military Park, make an obvious choice for protection and preservation for future generations. However, since the first designated National Park unit in 1872, there have been many places set aside in support of preservation for reasons that are less apparent than Gettysburg National Military Park. For instance, Eugene O'Neill National Historical Site is such a park with a significant resource, but presumably most Americans have never known of the playwright Eugene O'Neill or his impact on our society. Each unit is significant but understandably, some units represent a greater level of significance (National Park Service, 2003).

In addition to each park having differing levels of significance, does the designation process take into account other variables? When confronted with equivalent resources, do other variables such as, political affiliation, history, natural resources, land ownership, or location weigh into the decision making process? What persuades the United States Congress or the President of the United States in the designation process? For instance, what made Lowell National Historical Park and Keweenaw National Historical Park significant versus Blair Mountain, West Virginia? All three of the locations tell the story of labor unions but out of the three Blair Mountain has not been designated.

Why is a park designated? What makes one particular location more appropriate than another similar site? The preceding two questions cover a topic that is too extensive for one study to attempt to answer. Therefore, this research focus is on the spatial aspects of these questions, by compiling and analyzing the spatial facets of the National Park unit designation process. 


\section{Background}

With a bang of the gavel, the forty-second Congress of the United States of America altered the landscape in the United States as well as the World. At 2:45 P.M. on March 1, 1872, the heavily Republican laden forty-second Congress along with Republican President Ulysses S. Grant passed into law what is known today as the Yellowstone Act (The Yellowstone Act of 1872). The inscription in the header of the Yellowstone Act brought the federal government into the tourism industry by simply stating, "to set apart a certain tract of land lying near the headwaters of the Yellowstone River as a public park” (The Yellowstone Act of 1872). Those who voted on that bill most certainly did not see the profound implications that would lead to the formation of 393 National Park Units covering over 84,000,000 acres (Waldron, 2008).

It might be fitting that tourism and the economic proceeds that accompany tourism were one of the major contributors behind Yellowstone's formation. The push to establish Yellowstone as a federally protected area was rooted in preservation. This can be seen in the writings from the early explorers and fur traders of the Yellowstone area. Yellowstone had unknowingly been explored by the Lewis and Clark Expedition. Their expedition crossed the northern border of the park. Clark does record information collected from the indigenous inhabitants of the area who spoke of "at the head of this river ...loud noises like thunder, which makes the earth tremble...and the indigenous conceive it possessed of spirits” (Thwaites, 1905, pp. 266-67). After the Lewis and Clark Exhibition several more travelers wrote back east and to tell stories of the wondrous area. These stories were sometimes hard for people to believe, including the government. James Gemmell told his account of visiting Yellowstone for the first time; 
We reached a country that seemed, indeed, to be Nature's wonder world. The rugged grandeur of the landscape was most impressive, and the beauty of the crystal-clear water falling over huge rocks was a picture to carry forever in one's mind. (Wheeler, 1896)

The explorers as well as speculators that had visited the area saw the amazing natural landscape and swore to protect this for all Americans. The largest and most influential push for the protection of Yellowstone was from the Northern Pacific Railroad's financier Jay Cooke.

According to Richard Seller's (1997), Preserving Nature in the National Parks; Jay Cooke's urgent push for protection was to ensure that the Yellowstone country did not fall into private hands, but rather remained a federally controlled area. Cooke stating that government control would be easier to deal with than private landowners. From the first designation, National Park units served corporate profit motives. (p. 9)

The Northern Pacific Railroad owned a 200 mile wide right of way that would be located in or near the anticipated park. Once Yellowstone was designated and the boundary was set by Congress, the Northern Pacific Railroad had ownership of a 200 mile buffer conveniently drawn adjacent to the northern border of the park. What Cooke had created was the total control of the land connected to the entire northern boundary of Yellowstone. Thus, having the surrounding land federally protected, and having ownership of a railroad linking the east, created a monopoly on tourism dollars. This monopoly would benefit the Northern Pacific Railroad tremendously with increased ridership on the railroad. Mr. Cooke's railroad now controlled the only accessible 
entrance into the National Park, until the Union Pacific built a connector from the “Transcontinental Railroad” in 1908.

Map 1. Northern Pacific RR land grant near Yellowstone

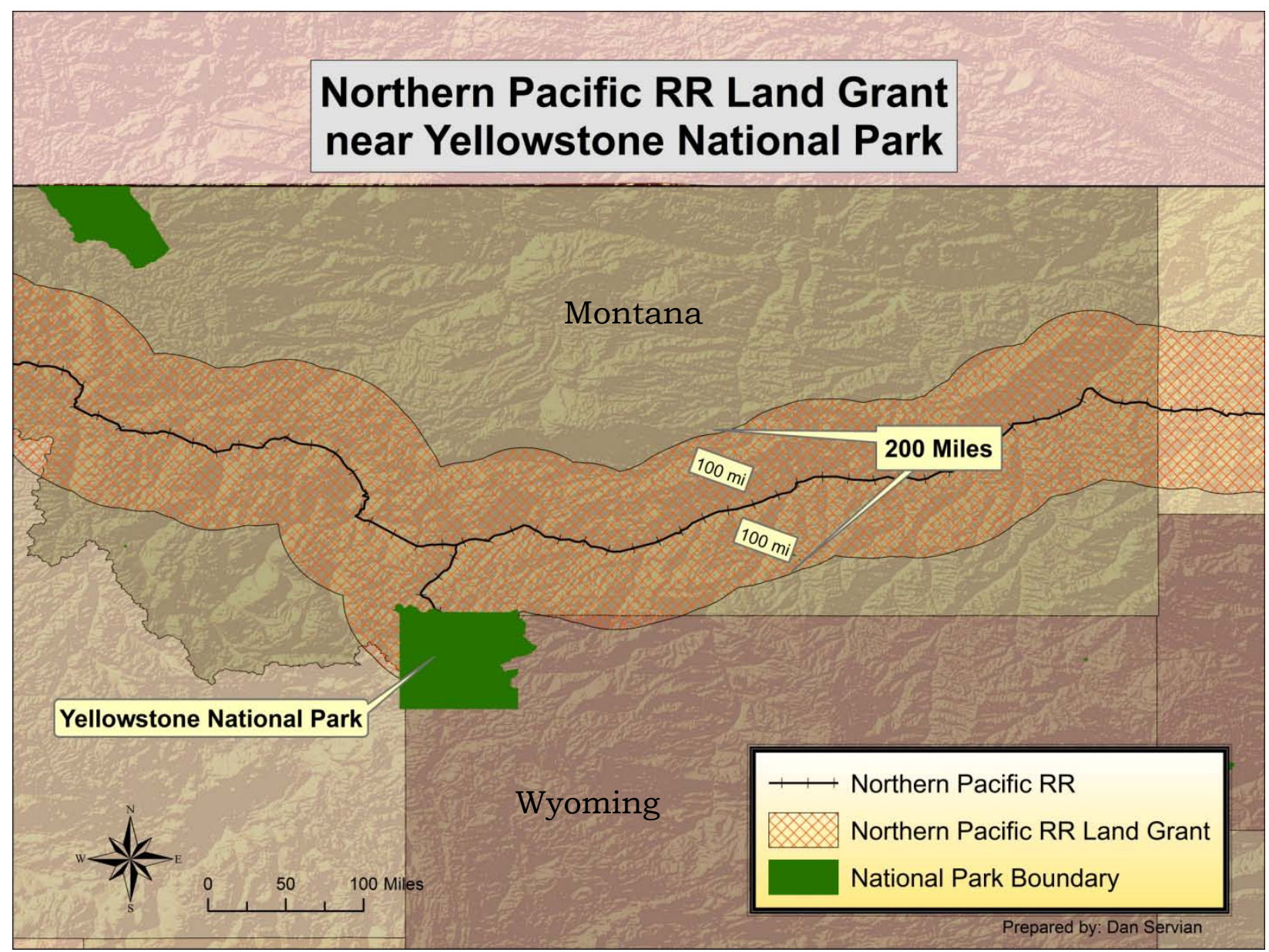

Following the 1872 designation of Yellowstone National Park it took another three years for Congress to establish another National Park unit. The second designated National Park unit in the United States was Mackinac National Park. Mackinac National Park was located in Michigan. In 1875, Senator Thomas W. Ferry of Michigan was concerned about the continued augmentation of private land ownership on the island. Senator Ferry was born on Mackinac Island and wanted it protected. For two years he lobbied Congress to establish Mackinac Island as the United States second National Park unit. His lobbing was successful and Mackinac Island 
became the nation's second National Park. Mackinac Island contained an Army garrison at Fort Mackinac, and the Army was cited with administration of the park. Within twenty years this would be the first National Park unit to be abolished (Dilsaver, 1997).

In 1895 Fort Mackinac was decommissioned by the U.S. Army and the state of Michigan feared that with the departure of the garrison, the park would fall into disarray. This led the Governor of Michigan to petition Congress to transfer the control of the National Park back to the state. Congress granted this motion to Michigan and the National Park status was abolished and Mackinac Island became Michigan’s first state park (Dilsaver, 1997).

After the designation of Mackinac National Park there were an additional 58 units established before the creation of the National Park Service in 1916 (Map 2). In those forty-four years Congress created one new unit designation, the National Monument. The majority of the National Park units established in this time period were located in the west with the exception of Civil War battlefields and statues. 
Map 2. National Park units between 1872 - 1916

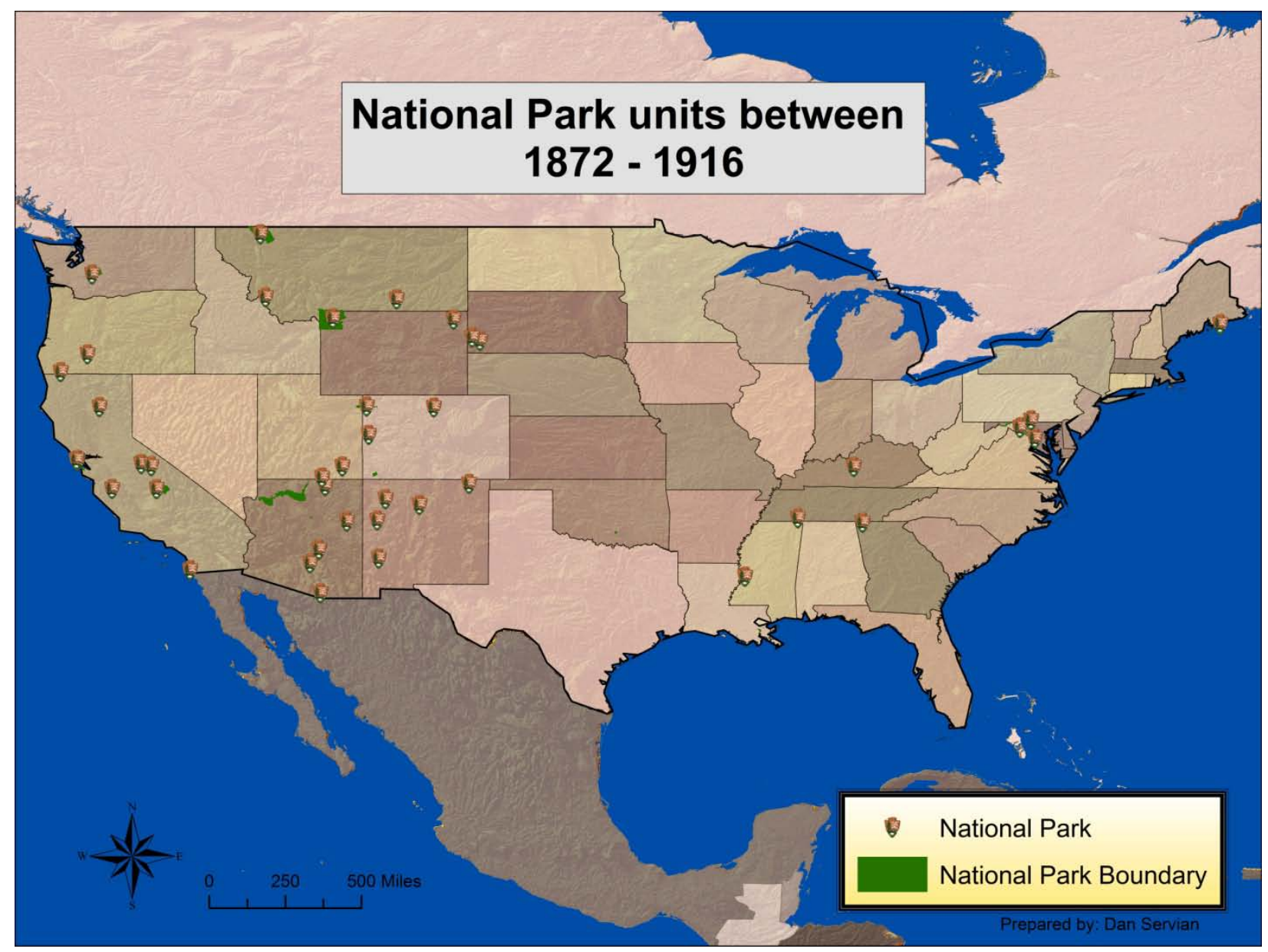

Until the establishment of the National Park Service, National Park units were managed independently on minimal budgets (Mackintosh, 2003). This changed with the passage of the 1916 Organic Act. This act created the bureau of the National Park Service housed under the Department of the Interior.

The Organic (1916) act also dictated the decree of the National Park Service which states: To conserve the scenery and the natural and historic objects and the wild life therein and to provide for the enjoyment of the same in such manner and by such 
means as will leave them unimpaired for the enjoyment of future generations (Organic Act of 1916).

Before the Organic Act, National Park units were managed primarily by the United States military. The military were not trained in resource management but by exploiting their engineering knowledge allowed them to competently manage the resource. While in Yellowstone National Park the Army created roads and hotels for the future influx of tourist. The Army also delved into species protection. In the beginning of the $21^{\text {st }}$ century, the Army began feeding herds of elk and buffalo to ensure winter survival. Both projects were successfully performed and were continued until relinquishment of control was handed over to the National Park Service in 1916 (Rydell \& Culpin, 2006).

After the passage of the 1916 Organic Act and the creation of the National Park Service, the following nine decades has seen the addition of 334 parks and 33 additional unit designations. In addition to the increased natural and historical resources, the National Park Service have seen many new laws and regulations enacted. Some of the most notable acts that have affected the National Park Service are:

- $\quad$ Historic Sites Act of 1935

- Wilderness Act of 1964

- National Historic Preservation Act of 1966 (NHPA)

- $\quad$ National Wild and Scenic River Act of 1968

- National Environmental Policy Act of 1970 (NEPA) 
- $\quad$ The Endangered Species Act of 1973

Each of the above acts has created a complex yet stronger National Park Service. But, one thing that has not changed is the controversy that the National Park unit designation process can create. For instance, the Omnibus Act of 2009 designated Patterson Great Falls National Historic Park. This park designation has focused the public on the entire designation process. The designation process for Patterson Great Falls began in 2001, when Congress passed the Great Falls Historic District Study Act of 2001 (Omnibus Appropriations Act of 2001). The 2001 act instructed the National Park Service to conduct a Special Resource Study of the Great Falls Historic District in Paterson, New Jersey.

A Special Resource Study determines if a resource meets appropriate criteria for designation as a unit of the National Park system (National Park Service, 2003). In 2006, the Special Resource Study of Great Falls Historic District in Paterson was completed by the National Park Service and submitted to Congress. The study found that although the site meets requirements for national significance, it does not appear to have particularly unique resources unlike those already represented in the national park system. Furthermore, the Special Resource Study states that Patterson Great Falls “fails to meet the criteria for suitability and feasibility” (National Park Service, 2003, p. 69). In laymen’s terms, that study stated that the National Park Service does not need another industrial revolution site and more importantly the site in question currently does not have an internal structure that without extensive financial startup investments, the park would not meet National Park Service standards. The National Park Service sent the Special Resource Study back to the Congress with their recommendations. 
Table 3. Simplified National Park designation process

- The President can designate a National Monument by excutive order

- The Secratary of the Interior can designate a National Historic Park by order

- The Congress typically investigates and debates the new designation

- The Congress authorizes the National Park Service to conduct a Special Resource Study. To investigate the feasability and suitability of designating a specific area as a National Park.

- Within three years, the National Park Service returns the study to Congress. Specifics of the report must include: rarity, integrity of resource, threats, similar resources

3rd already designated, public use potential, educational potential, costs, impact, and public support.

- Congress votes on the designation of the resource. This only occurs after the Sprecial Resource Study is returned and the National Park Service gives their impression on the resource in question

- The park is designated

- Further study is conducted

5th

- The park is not designated

After the National Park Service recommendation to not designate Great Falls Historic District as a National Park unit was received by Congress, Congressmen from New Jersey lobbied Congress to designate the park then, as the $393^{\text {rd }}$ National Park unit. In 2009, Democratic representative Bill Pascrell introduced bill H.R. 280 and was cosponsored by every New Jersey representative. Representative Pascrell was born in Patterson, NJ as well as the former mayor of the town. Representative Pascrell along with the other delegates of the New Jersey successfully lobbed and bill H.R. 280 was amended to the 2009 Omnibus Act. Omnibus acts are land management acts that are virtually guaranteed passage since nearly every state delegation had their own amendments added to the bill (Unknown, Congressman Bill Pascrell, 2010). 
Connections to Congressional representatives at a minimum facilitated the designation of Patterson Great Falls, just as political associations assisted Mackinac Island, the second designated National Park unit in 1875. The debate of park designation has not changed in the 137 years since the designation of Yellowstone. Research of past National Park unit designations has revealed that some of the designations had possible ulterior motives, other than just protection and preservation. Railroads, politics, economics, and countless other motives have created a park system that is the envy of the world.

\section{Definitions of terms}

Designation: “The act of indicating/ Identifying or appointment” (Merriam-Webster's, 2004, p. 238).

National Park unit: “Any area of land or water administered by the Secretary of the Interior through the National Park Service for park, monument, historic, parkway, recreational, or other purposes” (U.S. Congress, 1997, p. 5).

Spatial: "Related to the space around us, in which we live and function” (Clark, 2003, p. 6).

Distribution: “The frequency or amount at which a thing or things occur within a given area” (Environmental Systems Research Institute, No Date)

Spatial Distribution: “The locations of features or measurements or measurements observed in geographic space” (Clark, 2003, p. 30). 
Exploratory Data Analysis (EDA): Tukey (1977) states that the examination of data with minimal preconceptions about its structure through which it is hoped that relationships and patterns, at least some of which are unanticipated, will be uncovered.

Exploratory Spatial Data Analysis (ESDA): Luc Anselin is known as one of the developers of ESDA. He (1996) defines ESDA as focus is placed explicitly on the spatial aspects of the data, in the sense of spatial dependence (spatial association) and spatial heterogeneity. In other words, these techniques should aim to describe spatial distributions, discover patterns of spatial association (spatial clustering), suggest different spatial regimes or other forms of spatial instability, and identification of outliers. (p. 112)

Spatial Autocorrelation: Assists in testing the dependence, independence, or randomness of a dataset. Spatial autocorrelation is determined when a systematic pattern in the distribution is found (Bolstad, 2008).

\section{Purpose of the study}

The purpose of this study is to investigate the National Park unit designation process. The analysis will investigate any correlations and decipher any other factors that may influence the designation of a National Park unit. Examination of the data's relationships was executed by conducting exploratory data analysis along with exploratory spatial data analysis on the entire dataset. Investigations into the designation of National Park units will center within three overriding themes. The first theme is historical and is based upon on one of the core ideals of the National Park Service (Waldron, 2008). Politics is the second theme. The political theme arose from Congress enacting Yellowstone as the first National Park unit designation (The 
Yellowstone Act of 1872). The final theme in this analysis is geographical. The geographical theme was established via the Yellowstone Act and where it defines the boundaries of the park through natural and territorial boundaries (The Yellowstone Act of 1872). The overriding objective of this research is to discover corresponding spatial attributes of National Park units using historical, political, and geographical variables.

This paper's results will be focusing only on National Park units that reside within the continental United States. The utilization of both exploratory data analysis and exploratory spatial data analysis will answer the following research questions.

\section{Research Questions}

- What does the distribution of National Park units reveal?

- Does the spatial distribution of National Park units show a clustered or random pattern?

- What may have influenced this type of distribution of clustered or randomness?

- Are other factors involved in the designation processes? 


\section{Chapter 2. Literature Review}

Tobler’s (1970) first law of Geography states that "everything is related to everything else, but near things are more related than distant things” (Tobler, 1970, p. 237). This is the basis of this study's analysis. There are relationships between park designation and influencing factors such as: railroads, battles, historic places, politics, hydrology, and federal lands.

Historical

Since the birth of the United States of America, the nation has had an identity crisis. The young nation was open, wild, new and free for the majority to explore and make their mark (Yard, 1922). This viewpoint of America is double sided. Some may have viewed the United States as open, wild, new and free, which was a positive characteristic to some individuals, but others, typically European or the elite in the United States, may have thought that those characteristics mean only that the new nation is young, rough, and uncultured. Through subsequent decades the United States began building an identity (Yard, 1922). To protect this American identity, Congress as well as the War Department began protecting areas of national importance. Three historical variables that can be observed in National Park unit designations resulted from the creation of railroads, battles fought on United States soil, and historic places. 


\section{Railroads}

Yellowstone National Park was created for its grandeur but according to (Sellers, 1997) the park may have been designated additionally because of being spatially located near the Northern Pacific’s Railroad. Would the Yellowstone Act of 1872 have been created and passed if not for the railroad? Researching through many of the earlier National Park designations a correlation with railroads seems to be a constant theme.

Railroad companies became mired in enormous debt while building the great transcontinental railroads. The government awarded railroad companies land grants in order to aid in the financial burden of construction of the railroads. The land grants given to the railroad company's only were equity to either extract resources or construct settlements and sell the land off.

Johns (1996) noted, in order to win the financial support of potential shareholders, the railroads needed a way to entice the wealthy into riding the railroads in order to persuade them into believing that buying stock in the railroad was a solid financial investment. A well-developed campaign to attract settlers and sell real estate was part of proving to investors that the railroads would enjoy future prosperity, but scattered along any Western rail line were regions of rugged mountains, steep slopes, and poor soil unsuitable for settlement (p. 1).

But, according to Johns (1996) the railroad companies heard the reports of the majestic and awe inspiring lands located in the west and decided to embark on marketing tourism as a way to increase ridership. Along with increasing ridership, the railroad companies believed that 
tourism would increase settlement of the west and the sale of railroad land grants, thus, giving the stakeholders of the great transcontinental railroads vast wealth.

To aid in the settlement of the west as well as create transcontinental transportation, the United States government offered land grants to the railroads. Land grants are land parcels that were given to railroad companies after completing a specific mileage of track. Along with the land grants offered by the United States, the government also offered the company's financial capital per mileage of track built (Draffan, 1998). It is stated by Mercer (1982) that by the time of the Great Depression, the railroads would be in possession of an additional 4 million acres of federal land. When the additional 4 million acres are added to the previous land grants awarded to the railroads, gave the railroads control over roughly $9.5 \%$ of the total land in the continental United States. According to Draffan (1998), three quarters of all railroad land grants were eventually amassed by the four major transcontinental railroads: the Northern Pacific (40 million acres), Santa Fe (15 million acres), Southern Pacific (18 million acres), and Union Pacific (19 million acres).

During the Reconstruction era, passengers on the transcontinental railroads were looked at as a potential investor for the railroad companies. To aid in increasing ridership and thus increasing potential investors, the railroad companies marketed Yosemite and Yellowstone to the wealthy. Elites were the primary target because of the great expense that traveling on a cross country trip would incur (Johns, 1996). To help entice the well-to-do to take their western adventure, the railroads built grand hotels. Each of the major transcontinental railroads constructed large and extravagant resorts in these rustic National Parks and conducted a mass advertising campaign (Map 3, Graphic 1). Runte (1997) when writing about Glacier National Park (Graphic 2) noted "no structures were more elegant or varied than those provided by the 
Great Northern Railway [...] between 1911 and 1915 Hill personally supervised the construction of two sprawling lodges and a series of Swiss-style chalets” (p. 94).

Map 3. Railroad resorts

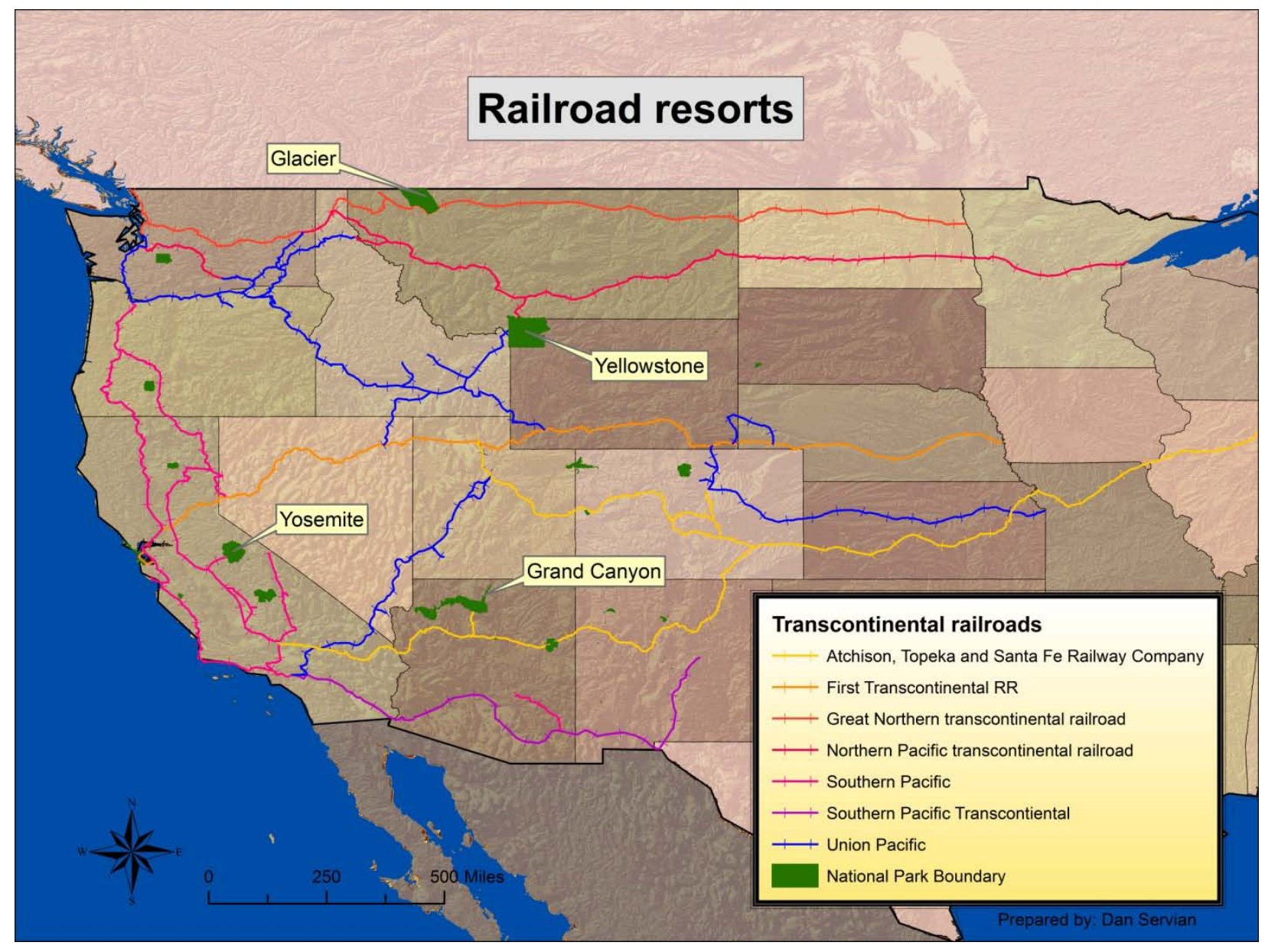

Graphic 1. Railroad advertising

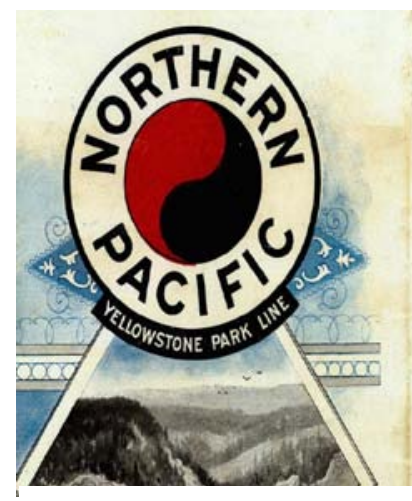

Graphic 1. An 1898 Northern Pacific Railroad advertisement promoting Yellowstone National Park (Cartography Associates. 2005).
Graphic 2. Lewis Glacier Lodge

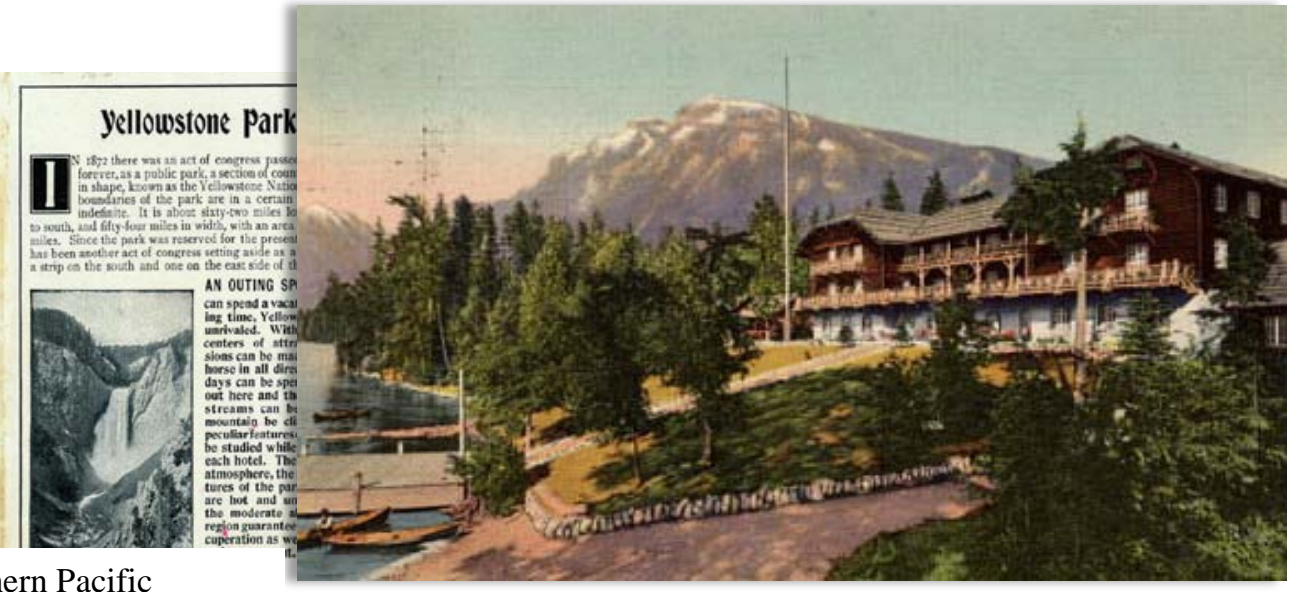

Graphic 2. Lewis Glacier Hotel with the original boat landing (Unknown, Lake McDonald Lodge additional photos, 2009). 
Battles

By the rude bridge that arched the flood, their flag to April's breeze unfurled, here once the embattled farmers stood, and fired the shot heard round the world. (Concord Hymn, Ralph Waldo Emerson)

In comparison to Europe, America has a relatively short history. The United States of American was created when colonists of England took up arms and decided to revolt. This shot heard round the world took place at Concord, Massachusetts. Concord became a place of significance to citizens of this new nation as well as for many people around the world (National Park Service, 2000). When Congress authorizes the National Park Service to conduct a Special Resource Study, Congress is following the Organic Act (1916) and asking if a particular location "possesses nationally significant natural or cultural resources and represents one of the most important examples of a particular resource type in the country” (p. 4549). Obviously the battles that took place at Lexington and Concord would fit the Organic Acts specifications. But surprisingly, this most important battle did not become an official National Park unit until 1959 with the designation of Minute Man National Park.

Twenty years after the Civil War, Congress authorized the War Department to preserve historic battlefields, forts, and memorials. The first to be protected by the War Department was Chickamauga and Chattanooga National Military Park in 1890. For the next 40 years the War Department protected many significant military instillations and battlefields.

Mackintosh (2003) reveals the changed when Franklin D. Roosevelt took office in 1933, Albright, the director of the National Park Service, accompanied the new president on a trip to Shenandoah National Park and mentioned his desire to acquire all the military parks and Roosevelt agreed (p. 1) 
Since inception of Yellowstone National Park there has always been a connection between the United States Military and National Park units. One less known connection between the two occurred between the $9^{\text {th }}$ Calvary "Buffalo Soldiers" and Yosemite National Park. The all black Calvary unit was created in 1866 and conducted missions in the Indian Wars. According to Shelton (2007), in 1904 nearly 400 troops from the $9^{\text {th }}$ Calvary protected Yosemite, Sequoia, and Grant National Parks (later renamed Kings Canyon National Park). Shelton (2007) believes that their obscurity to the history of the National Parks resides in racism brought on by a lack of written records about their accomplishments. But, many believe that the Buffalo Soldier's should be credited with saving Yosemite from being destroyed (Shelton, 2007).

There are 25 battlefield related National Park unit designations. The majority of these parks lie within the Mid-Atlantic region. The only battlefield related National Park unit designation west of the Mississippi is located in Montana at the Little Big Horn. There have been many battles that have been fought on United States soil. Since 1776 there have been six major wars that took place within United States borders (Table 4). In this analysis, the data points that represent major battles that took place on American soil were signified by the National Park Service as major or important and correspond with (Table 4) the major wars fought on American soil (Heritage Preservation Services, No Date).

Table 4. Major wars on U.S. soil

\begin{tabular}{|lll|}
\hline & Major Wars fought on United States soil \\
\hline French \& Indian War & Revolutionary War & War of 1812 \\
\hline Civil War & Indian Wars & Mexican American War \\
\hline
\end{tabular}




\section{Historic Places}

On the National Park Service's website (www.nps.gov), their introductory webpage has a link to history. History and National Park units go hand in hand, be it the history of the American industrial revolution or the geological history of a volcano. One expects to have the opportunity to learn about the past when visiting any National Park unit. Learning about the heritage, intellectual philosophy, triumphs, and sorrow of a nation will instill pride or humility in its citizens (Yard, 1922).

In 1922 Robert Yard wrote an article in the now defunct magazine The Survey and wrote about how the National Park Service and more importantly, the United States Congress were "unaware, we are undergoing a new evolution of patriotic pride that is national in a real sense" (Yard, 1922, p. 547). Yard writes about how with the invention, and now mass consumption of the automobile, that National Park unit visitation is finally available to the common man. The national pride was swelling in the early 1920's partly because of the union movement (Yard, 1922). Additionally, national pride was increasing given that the majority of soldiers had come home after the end of World War One, which ended with the Treaty of Versailles on June 28, 1919. According to Yard (1922), the unawareness of the National Park Service and Congress was a missed opportunity for education and interpretation of the natural museums or National Park units and that preparation should have been made for the increased visitation.

In 1966 the United States Congress passed the National Historic Preservation Act.

Excerpts from the 1966 act states that: the spirit and direction of the Nation are founded upon and reflected in its historic heritage, the historical and cultural foundations of the Nation should be preserved, the preservation of this 
irreplaceable heritage is in the public interest.

(National Archives and Records Administration, 2010, p. 298)

The National Historic Preservation Act (2010) began the movement of protecting America's heritage. The act also created the National Register of Historical Places, which protects important buildings, districts and places for future generations. This act also dictated that several National Park unit designations will automatically be placed on the register once designated. The designations that fell under this provision included: National Historic Landmarks (NHL), National Historic Sites (NHS), National Historical Parks, National Military Parks/Battlefields, National Memorials, and some National Monument (Public law 89-665, p 915).

\section{Political}

As stated earlier, Great Falls Historic District at Patterson and the former National Park of Mackinac Island illustrate how politics may be intertwined with the designation of National Park units. The creation of a National Park unit is completed by Congress, President, or sparingly by the Secretary of the Interior (Table 3). The "people" may pressure their congressional representatives for a place to be designated as a National Park unit but the final decision is up to their political representatives. Not even the National Park Service can make a final decision on a designation. Politics take many forms when researching a National Park unit. Obviously the designation process is in itself $100 \%$ political but so are many other aspects. Politics in National Parks can take the form of regulations, user fees, and social aspects such as 
constitutional right to bear arms (Fehl, 2010). The laws and regulations that impact National Park units are crafted by Congress. Regulating federal resources is Congress's responsibility owed to their constituents just as creating economic prosperity is (Tufte, 1978).

Part of representing an area is to improve the lives of the residents and this is partly accomplished by improving economic conditions (Tufte, 1978). The economic benefits of having a National Park unit designated can be very beneficial to that region (Great sand dunes national park and preserve act, 2000). Politicians know this and recently this could be seen in the congressional debate for the Great Sand Dunes National Park and Preserve Act of 2000. Democratic House Representative Degette from Colorado testified to Congress and was recorded in the Congressional record dated October $24^{\text {th }}$.

The Congressional Record (2000) confers: This designation will also benefit the people of southern Colorado, not only because it protects one of their most treasured natural resources, but also because such protection will boost the local economy. Preserving natural resources provides Western Slope communities with a comparative advantage over other rural areas for diversifying their economy by enhancing their ability to attract and retain businesses and a talented workforce. Protecting public lands provides many economic benefits and maintains the natural capital that forms the foundation of Colorado's identity, quality of life and economic well-being. (p. H10714)

The United States Congress is not the only political body that can establish a National Park unit. The President of the United States also plays a role in the formation of a National Park unit designation. In 1906, the United States Congress passed the American Antiquities Act 
(1906), which authorized the President to "proclaim historical landmarks, historic and prehistoric structures, and other objects of historic or scientific interest that are situated upon the lands owned or controlled by the Government of the United States to be national monuments” (p. 225). Only limiting the President to designation on federal lands may seem restrictive but according to the National Atlas of the United States (2003), the United States Federal Government is in possession over roughly 650 million acres or in other words, approximately 30\% of the total land in the United States of America.

Much of the legislation that has involved the protection of natural resources has had an impact on National Park units. From the Antiquities Act of 1906 to the National Wild and Scenic Rivers System act of 1968, the shape and size of the National Park units and the National Park Service have transformed with society. This has created a complex yet strong branch of the federal government that attempts to bridge geographical and political differences to manage every National Park unit for all Americans.

\section{Geographical}

Along with American history, geography plays an important role in the designation of a National Park unit. When Yard (1922) explained about the religious feeling one feels when viewing El Capitan in Yosemite for the first time, he was speaking about location. If it was not for the location of the Sierra Nevada's, Yosemite most likely would not exist. Or when one reads the poetic writings of Marjory Douglas’s influential novel River of Grass, we are envisioning Everglades National Park and the location of the park with its unique slow wide 
river. American's, in addition to other peoples of the World, were intrigued by John Wesley Powell's expedition down the Colorado River and his near death experiences near the Grand Canyon and Glen Canyon, which are now both National Park units.

Humans have always been drawn to water. It provides necessary essentials for life. It seems fitting that the National Park Service would protect resources associated with water. The National Park Service has protected 26 water related designations. The water related areas include: rivers, lakeshore, and seashores. Observations of the history of the United States illustrate the importance of rivers and oceans and how they were crucial to the creation and expansion of America.

Johnson (1915) explains that the commercial highways of the American colonies were the ocean and the rivers. Starting along the bays and at the head of tidewater navigation, settlement advanced inland along streams and spread thence laterally over the country by way of the tributaries or rivers. (p. 13)

Johnson (1915) foretold why waterways will be designated as National Park units by emphasizing the importance of waterways to the evolution of the United States. Palmer (1993) states the importance of water to humans by stating in his narrative "with the waters and shorelines and their inseparable valleys, canyons, the rivers represent perfection of the natural systems constitute no less than life on Earth” (Palmer, 1993, p. 4). 


\section{Exploratory Data Analysis (EDA)}

Far better an approximate answer to the right question, which is often vague, than an exact answer to the wrong question, which can always be made precise. J. W. Tukey (1962)

What Tukey is explaining is the basis of exploratory data analysis which allows the researcher to obtain an understanding of the data at hand and before the extensive analysis process. This will allow your data to show where to look and answer the correct question. This process can sometimes be considered controversial in reference to research. This contention is seen in some statistical text books that are utilized at many universities. These books urge caution when utilizing EDA and occasionally consider exploratory data analysis as cheating (Moore, McCabe, \& Craig, 2009).

"In a quest to find a way to make statistical graphics more interactive, pioneering statistician John Tukey along with researchers at AT\&T Bell Laboratories began to develop the foundations of exploratory data analysis” (Anselin, Interactive techniques and exploratory spatial data analysis, 1999, p. 252). Anselin was expanding on what Tukey was stating and agreed that more emphasis needs to be placed on the data. Research concludes that exploratory data analysis is a way of thinking about the data. Exploratory data analysis is a statistical technique that makes use of graphs and other summaries to describe variables in a given dataset (Tukey, 1977). The graphs that may be used in exploratory data analysis include but are not limited to: steam/leaf plot, box plot, pie chart, histogram, scatter plot, and time series analysis. One important aspect of exploratory data analysis is to understand the dataset and to get a feel for it. Tukey (1997) stresses that exploratory data analysis is an art or a new way of thinking. Going 
through steps to learn about and understand data will aid in creating hypothesis for further exploration. John Tukey was one of the founding fathers of this type of analysis and wrote the appropriately titled 1977 book Exploratory Data Analysis in which he writes about the process. In Tukey's (1977) book he explains that EDA is an exploration or examination of data with minimum bias on its descriptive statistics wherein the researcher may reveal patterns, correlations, and outliers. Tukey (1977) also clarifies that exploratory data analysis will reveal anticipated as well as unanticipated observation that will point the researcher to the most appropriate avenue for further research.

\section{Exploratory Spatial Data Analysis (ESDA)}

The fundamental nature of Exploratory Spatial Data Analysis builds on simple descriptive statistics and robustness. Descriptive statistics looks to describe characteristics of data rather than infer conclusions about the data as inferential statistics does (Anselin, 1999). Descriptive statistics utilize many statistical summaries such as: stem and leaf plot, histogram, scatter plot, Q-Q plots, and time series analysis. ESDA also needs robustness in its statistics, which is typically completed by use of the median as the measure of center versus the mean. By utilizing the median as a measure of center will make the statistics more resistant to outliers (Moore, McCabe, \& Craig, 2009).

Exploratory spatial data analysis, being an extension of EDA, utilizes many of the same techniques. Both EDA and ESDA look for patterns in the data. Allowing outliers to speak and not be a reason for failure (Anselin, 1999). ESDA builds on descriptive statistics, used by EDA, 
by adding spatial aspects to the data. With both EDA and ESDA, researchers usually lack a specific hypothesis to test. Researchers link statistical and visual methods to observe patterns and or structure. This will aid in finding a hypothesis and help to create questions to be answered in future research. Exploratory spatial data analysis is a way to graphically map out datasets (Fotheringham, 1992).

A major characteristic of ESDA is the concept of brushing and linking. Brushing which has been used in a basic sense in EDA, allows the user to use their computer mouse and curser to actuate a region of a graph or database and the corresponding information of the selected area is provided. In ESDA, brushing/linking is taken to a more complex level by connecting map data to graphical data as well as to a database (Fotheringham, 1992). Highlighting one of the corresponding points, lines, or polygons in a GIS will provide all of the information from relating analysis. For example, if a research was conducting an analysis on the U.S. State census data. The researcher can gain the sought after data about a particular state by “clicking” for instance, the state of West Virginia. Once the user activates the state of West Virginia all of the corresponding databases and analysis will be shown about the state of West Virginia. This can also be conducted in reverse order. For instance, if a researcher is analyzing state rainfall totals and more specifically would like to see which states are in the top $10 \%$ of total yearly rainfall. The researcher would calculate in their statistical database to find the top $10 \%$. Once the database has calculated the answer, all of the corresponding states would be highlighted. This allows the research to visually look at the data geographically and examine if there are correlations or interesting outliers via a map (Fotheringham, 1992).

The use of spatial analysis makes it possible to view the relationship of research questions. Anslene, Dodson, \& Hudak (1993) gave an explanation of spatial analysis in their 
research and write that "broadly speaking, spatial analysis can be defined as the formal quantitative study of phenomena that manifest themselves in space” (p. 5). The analysis of data spatially can be simply conducted by just observing the data via a map or other visual output. Looking at the data, such as rivers, and how it spatially relates with other objects or data, such as population of a town or county. This observation may provide a possible research question to answer, direction in ones research, or provide an explanation to an outlier or pattern that was noticed in the data (Fotheringham, 1992).

This research uses some of the spatial analysis techniques that were conducted in Oh and Jeong (2007) study, where the authors amalgamated census data with density figures that were based on location. This disclosed to Oh and Jeong (2007) the spatial distribution of the subject area in their research. Oh and Jeong (2007) conducted spatial analysis and observed the relationships to find acceptable locations for the creation of a park in Japan.

Observing clusters in exploratory spatial data analysis software will show spatial autocorrelation. Applying both univariate and bivariate methods that have been used to find autocorrelation by Reed \& Burkhart (1985) and Sheehan \& Welsh (2009) will aid this research to find positive and negative spatial autocorrelation. Spatial autocorrelation assists in testing the dependence, independence, or randomness of a dataset (Bolstad, 2008). Spatial autocorrelation is determined when a systematic pattern in the distribution is found. When neighboring data is similar they are positively spatially autocorrelated. When neighboring data is not similar then they are negatively spatially autocorrelated. When there is no pattern found, than the distribution is said to be random (Bolstad, 2008). 


\section{Chapter 3. Methodology}

The methodological section of this study followed a three step process. The three step process began with collecting the needed data and manipulating the data to the required specifications that allowed for calculations in exploratory data analysis as well as for observations in exploratory spatial data analysis. After the data had been collected and manipulated to the functional specifications, the next step was the computation and observations of the data via exploratory data analysis. Once an understanding of the data's trends and correlations had been learned, the final step in this analysis commenced. The final step utilizes exploratory spatial data analysis, which permits the data to be explored spatially, allowing the data to show spatial distributions and clusters

\section{Data Collection \& Manipulation}

The database was collected from multiple sources. The National Park unit boundary layer was obtained from the National Park Service data store. The National Park visitor statistics was obtained from the Nation Park Service Statistics department. The United States layer which contained state boundaries was downloaded from the National Atlas website along with county boundaries, roads, cities, zip code boundaries, and railroad layers. The National Atlas is maintained by the Department of the Interior. Demographic data was collected from the 2000 U.S. Census. The U.S. Census is administered by the U.S. Census Bureau. Finally, the political affiliation of state representative, total congressional control, and the presidency were gathered 
from the Biographical Directory of the United States Congress 1774 - present website. The Biographical Directory of the United States Congress 1774 - present website is hosted and operated by the United States Congress.

The layer representing the National Register of Historic Places was obtained via the National Park Service data store. The analysis also utilized a hydrology layer that represented major rivers and shorelines in the United States and this was obtained from the National Atlas. Three GIS layers included in this analysis were created via manual digitization. These digitized layers are: major battles on American soil, transcontinental railroad, and the railroad land grant layer. The National Park Service dictated what was considered a major battle and was gathered from NPS.gov. To create the transcontinental railroad file two sources were used. The first was a historic map from 1881 of the transcontinental railroads and was obtained from the Bruce C. Cooper collection. The second, a national railway layer obtained from the National Atlas was used to correlate the Cooper map and aid in digitations. The railway land grants were created by implementing a buffer on the transcontinental railroad layer. The parameters for each land grant was obtained from Mercer (1982) book titled Railroads and land grant policy.

To utilize the 2000 U.S. Census data multiple joins and spatial joins were conducted. A join in GIS creates a relationship and appends two separate tables via a common field, such as federal county id (Environmental Systems Research Institute, No Date). The goal was to create a master county polygon layer that contained population, median income, and proper location. The federal county ID was calculated to serve as the key and allow for the joins between the tables (Graphic. 3). This created one master database/attribute table that contained all desired data that related to United States counties. 
Graphic 3. Federal county ID
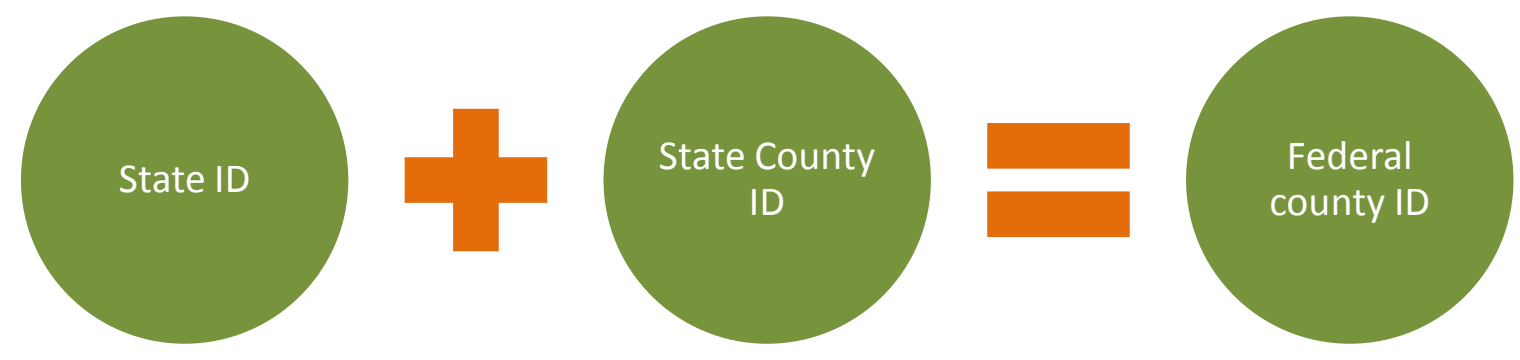

The National Park unit attribute table was expanded by both manual calculations and tables join. The original National Park boundary contained the park abbreviation, name, and designation. To complete the analysis the addition of the year of designation, political affiliation at time of designation and a simplified descriptive designation needed to be calculated. Tables join between the National Park anniversary .dbx file and the National Park boundary file was conducted via the park abbreviation. Manual computation of both the simplified descriptive designation and political affiliation at the time of designation was conducted. All manually calculated data was checked multiple times for errors. 


\section{Exploratory Data Analysis}

The first step of the analysis was to explore the data. Exploratory data analysis gives the researcher the ability to learn about the data and look for outliers, unique peaks or valleys, and develop transformations if necessary. Both univariate and multivariate data were explored by observing: stem and leaf plots, histograms, Q-Q plots, Semi-variograms, and a time lines. The exploratory analysis was conducted in MiniTab 15.

The National Park boundary file and the county census datasets were observed in this process. While observing the National Park boundary file in the exploratory data analysis phase attention was placed on the following variables: designation date, political affiliation, simplified designation description and location. The county census data calculation focused on population and median income. All trends and correlations were retained for further analysis in a spatial environment.

\section{Exploratory Spatial Data Analysis}

The trends and correlations that were observed in the exploratory data analysis phase as well as the distribution of the influencing factors that were found through research were conducted. Spatial representation of the individual themes can be seen in the following table (Table 5). All data tables and layers were analyzed in both univariate and multivariate environments. Each database and spatial layer were combined, when feasible, to observe if any correlations occurred. 
Table 5. Theme spatial representation

\begin{tabular}{|l|l|}
\hline Historical & $\begin{array}{l}\text { Spatial Representation } \\
\text { Historic Places, major battles }\end{array}$ \\
\hline Political & $\begin{array}{l}\text { Political affiliation at the date of unit } \\
\text { designation: President, Congress, state House } \\
\text { and Senate representatives of the receiving } \\
\text { state }\end{array}$ \\
\hline Geographical & Hydrology (shoreline, streams), federal land \\
\hline
\end{tabular}

Both Global and Local spatial autocorrelation tests were performed to observe autocorrelation on the research data. To begin either test a weight matrix was created. The weight employed in this analysis was a queen weight matrix, which is a contiguity-based matrix. The queen weight will conduct the analysis by analyzing neighboring polygons and vertices. . Global Moran's I tested for spatial autocorrelation across the entire analysis area. This test can be performed on univariate as well as bivariate dataset. Global Moran's I was calculated in both GeoDa and ArcMap. Local Indicators of Spatial Autocorrelation (LISA) is a spatial autocorrelation test that looks for autocorrelation at the local level and is also tested in GeoDa and ArcMap. The weights created will conduct tests both for Global Moran's I and Local Indicators of Spatial Autocorrelation but need to be created for each dataset. 
Chapter 4. Results

The results chapter is separated into three sections. The first section shows the results of EDA calculations of political affiliation. The second section displays the results from analysis of the themes. The final section explores the data spatially. Only interesting or significant results were presented.

\section{EDA of political affiliation}

The significant findings or intriguing outliers from the exploratory data analysis phase were found within the National Park boundary data that was joined with the political theme data. When observing all National Parks from 1872 to 2007 trends were found in graphs 1-5.

Graph 1. Observing the designations in terms of acreage by the political affiliation of the President and Congress (A)

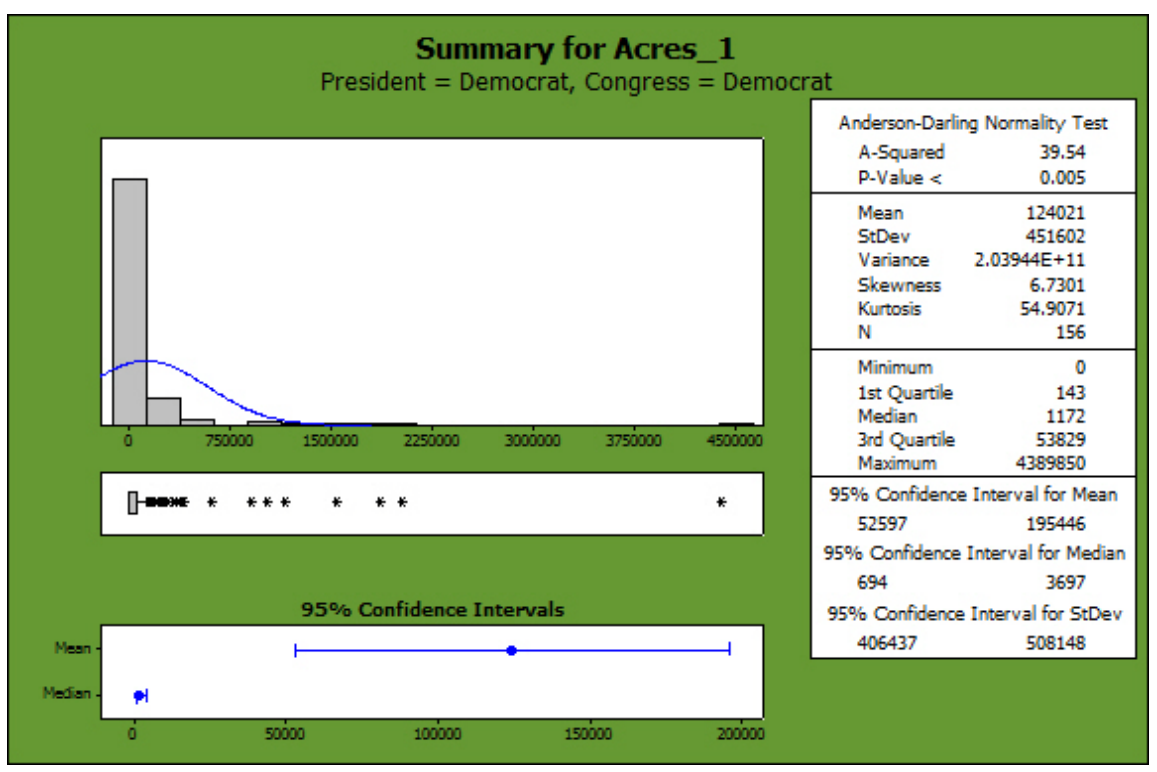


Graph 2. Observing the designations in terms of acreage by the political affiliation of the

President and Congress (B)

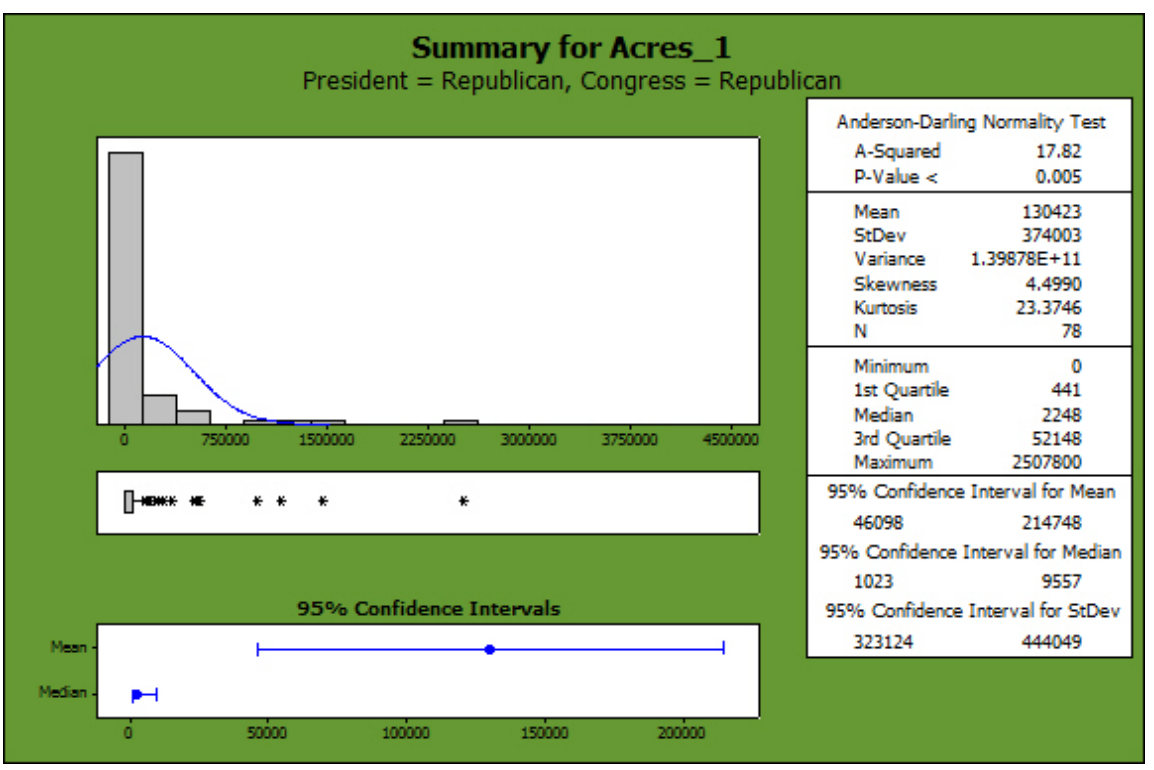

Graph 3. Observing the designations in terms of acreage by the political affiliation of the

President and Congress (C)

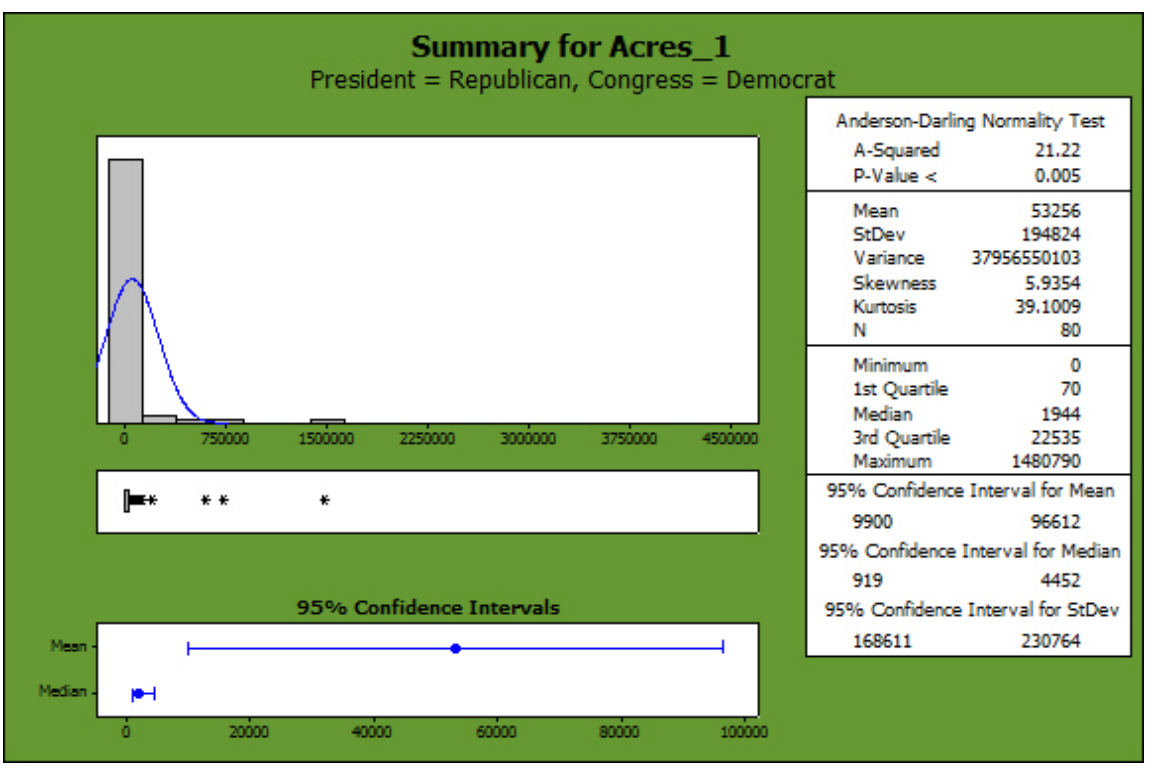


Graph 4. Observing the designations in terms of acreage by the political affiliation of the

President and Congress (D)

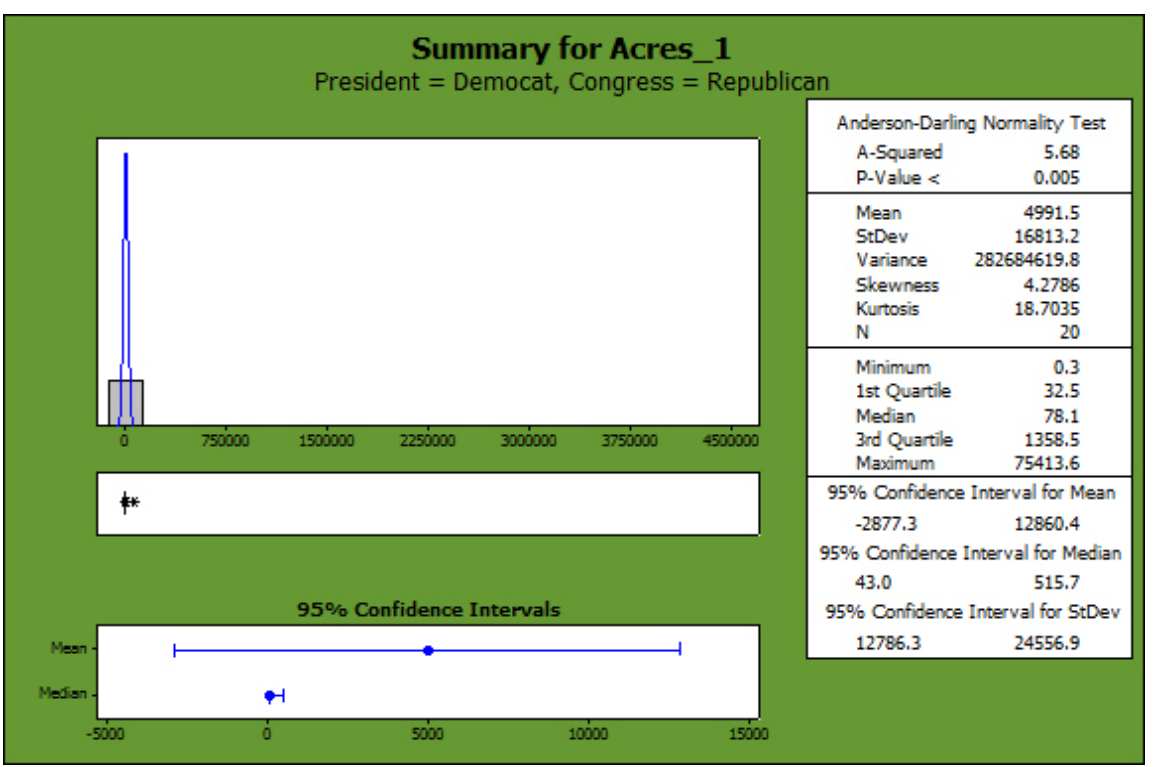

Graph 5. Observing the designations in terms of acreage by the political affiliation of the President and Congress (E)

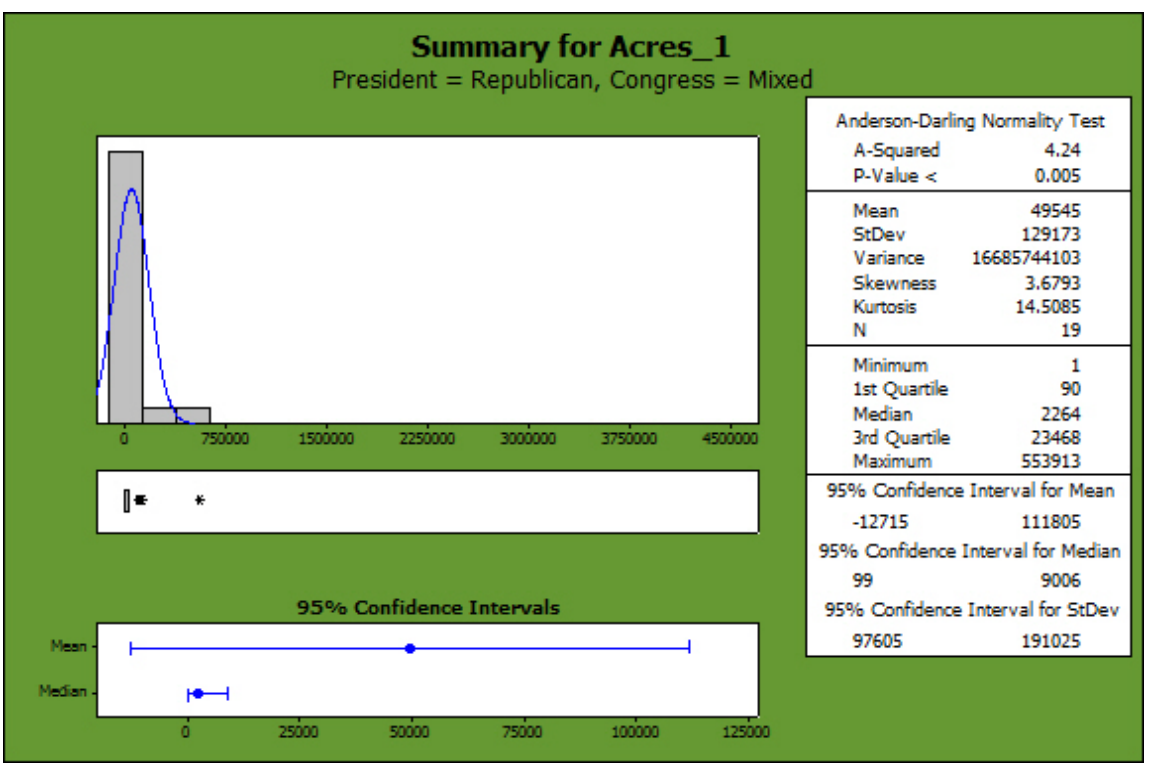


There are two findings that stand out in graphs 1-5. First, when a Democrat is President and there is a Republican majority in control of Congress, drastically less acreage has been designated compared to the other scenarios. The median for the Democratic President with a Republican majority in Congress is 78.1 acres while the median average of the other four scenarios is 1,907 acres. The 78.1 acres only accounts for just over $1 \%$ of the total median average (7,706.1 acres). The second significant finding is the lack of a graph that represents a Democratic President with a mixed controlled congress. This is because there has only been one National Park unit established with this criterion. The only National Park unit to be designated was Little Big Horn National Monument in 1886 and was 786 acres in size. An interesting outlier that was revealed in this data set was observed in the number of National Park units designated via political affiliation. Graph 1 shows that 156 National Park unit designations or $44 \%$ of all designations for the years 1872 - 2007 were designated when there was a Democratic President with Democratic majority in Congress. Versus, 78 units or $22 \%$ of the total National Park unit designations were created under joint Republican control of the Presidency and Congress.

The following graphs demonstrate a relationship between the President's political affiliation, Congressional majority political affiliation, and the political affiliation of the state that the National Park unit is located. The state political observations are for both Senate and House representation. The use of the simplified designation description was used for the following graphs:

- $1=$ Military

- 2 = Historical

- $\quad 3=$ Water related 
- 4 = Memorial

- 5 = Monument

- 6 = National Park

- 7 = Recreation

- 8 = Park

Graph 6. 22 Historical designations

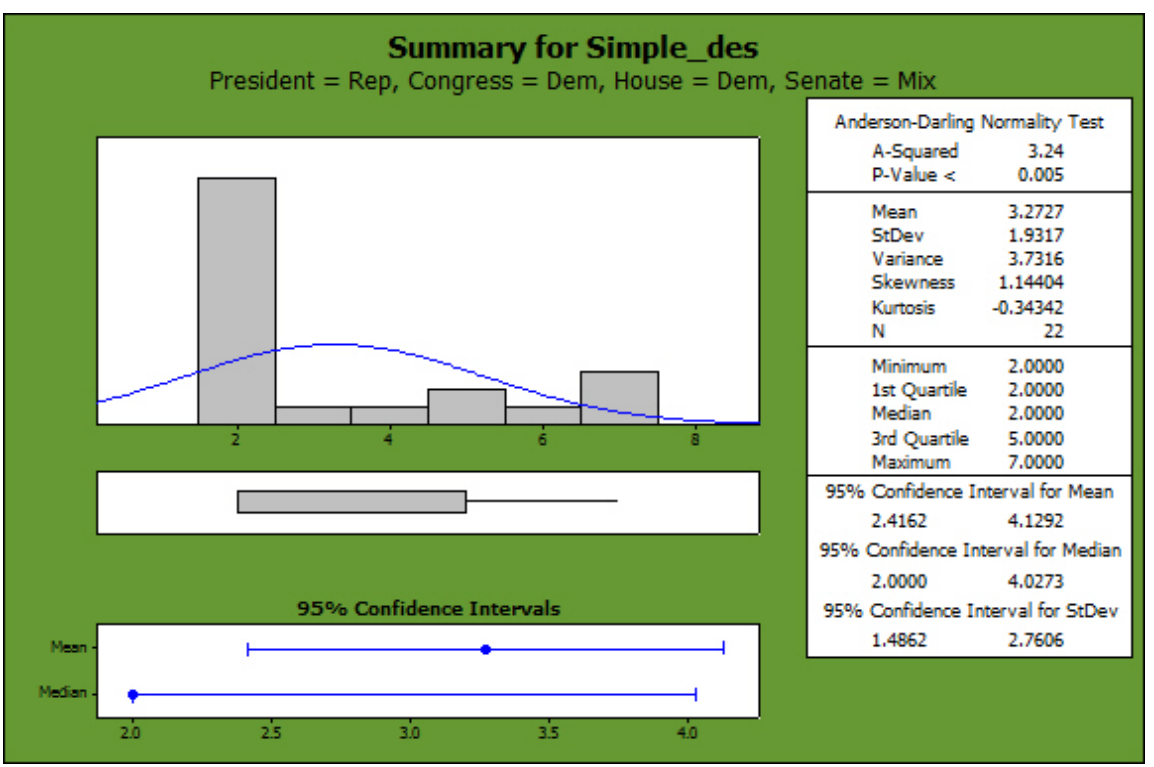

This graph shows that when there is a Republican President, Democratic Congress,

House Representative Democrat, and a Mix Senate representation that 14 out of 22 or $64 \%$ of the time a historical National Park unit was created, which justifies the median average of two that represent historical. 
Graph 7. Majority National Monuments and National Parks

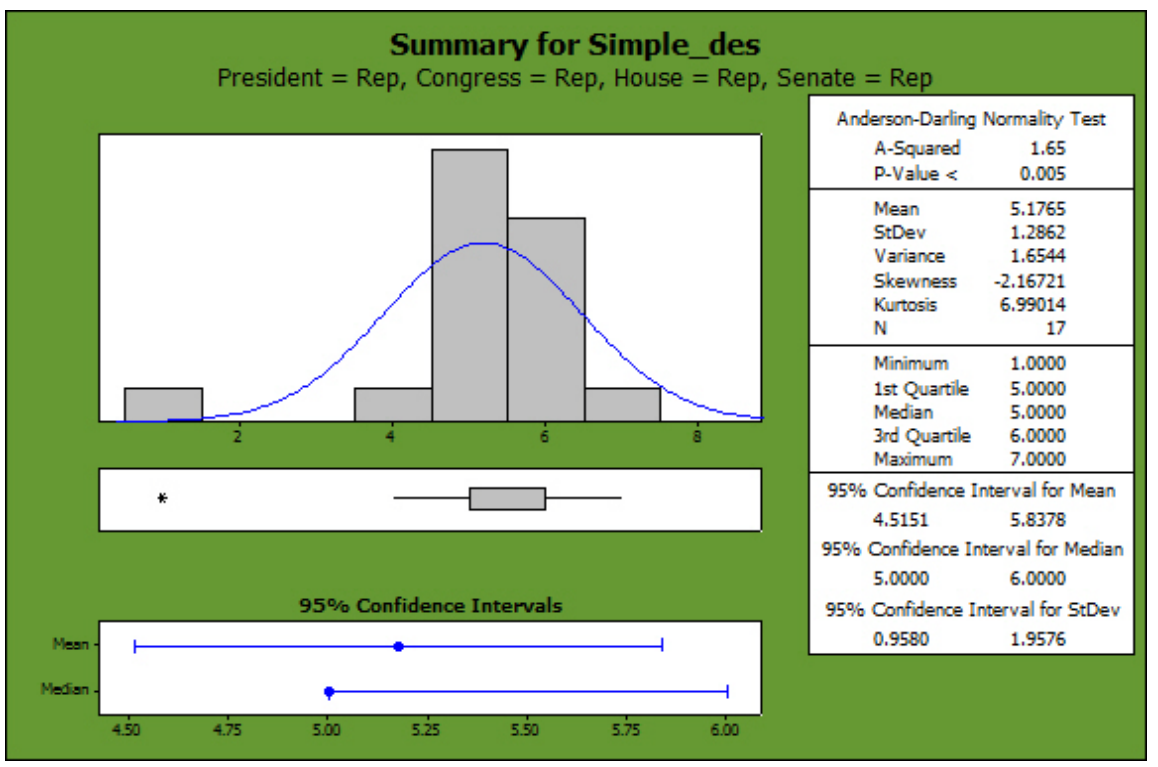

Graph 7 represents that when Republican control is across the board, typically a National Monument or a National Park will be designated. What is most important to take from this graph is the lack of water related and historical National Park designations.

Graph 8. Near normal distribution

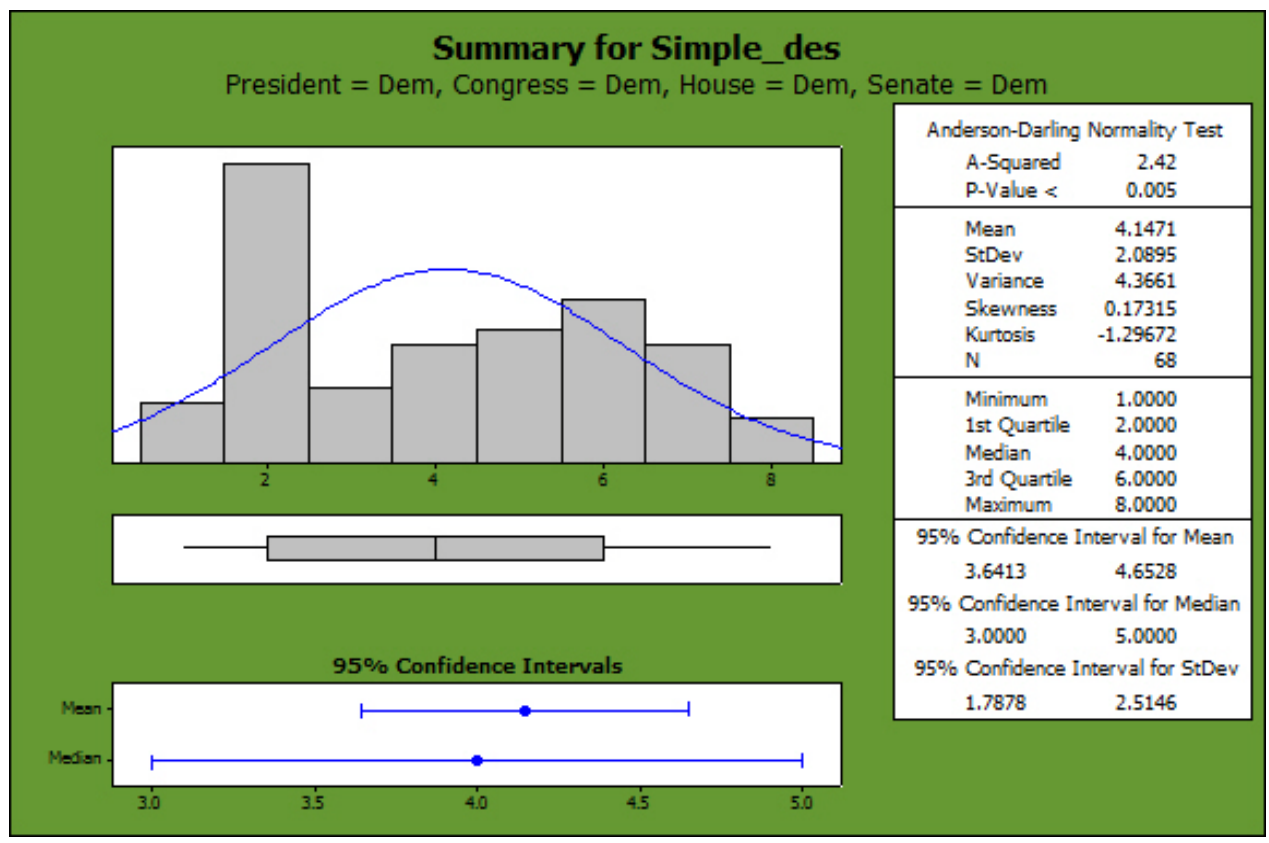


Graph 8 shows a near normal distribution. When there are Democrats in charge of all four variables, the distribution is spread around. The historical designation is an outlier that does skew the data but the median is still 4 . This political group also designated the most out of any National Park units with a total of 68 units. It is interesting to note that when the opposite occurred and the Republicans were responsible for the designation the historical designations were non-existent and only 17 designations occurred. But, graph 8 demonstrates that when there is Democratic control particular focus was paid to historical units.

Graph 9. Pie chart of presidential designations for all National Park units

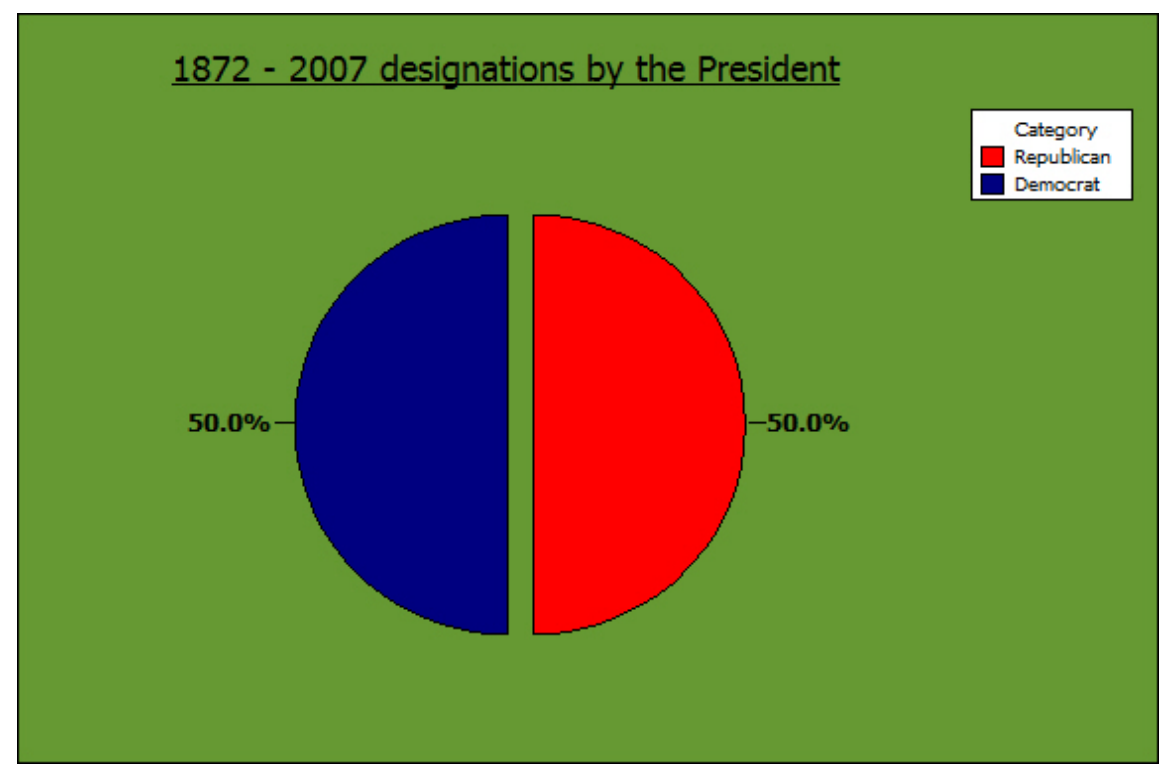

A surprising result that shows that there has been a 50\% split in the number of designations by either politically affiliated President. This result will conflict with the next graph (Graph 10). 
Graph 10. Pie Chart of the political affiliation of the congress

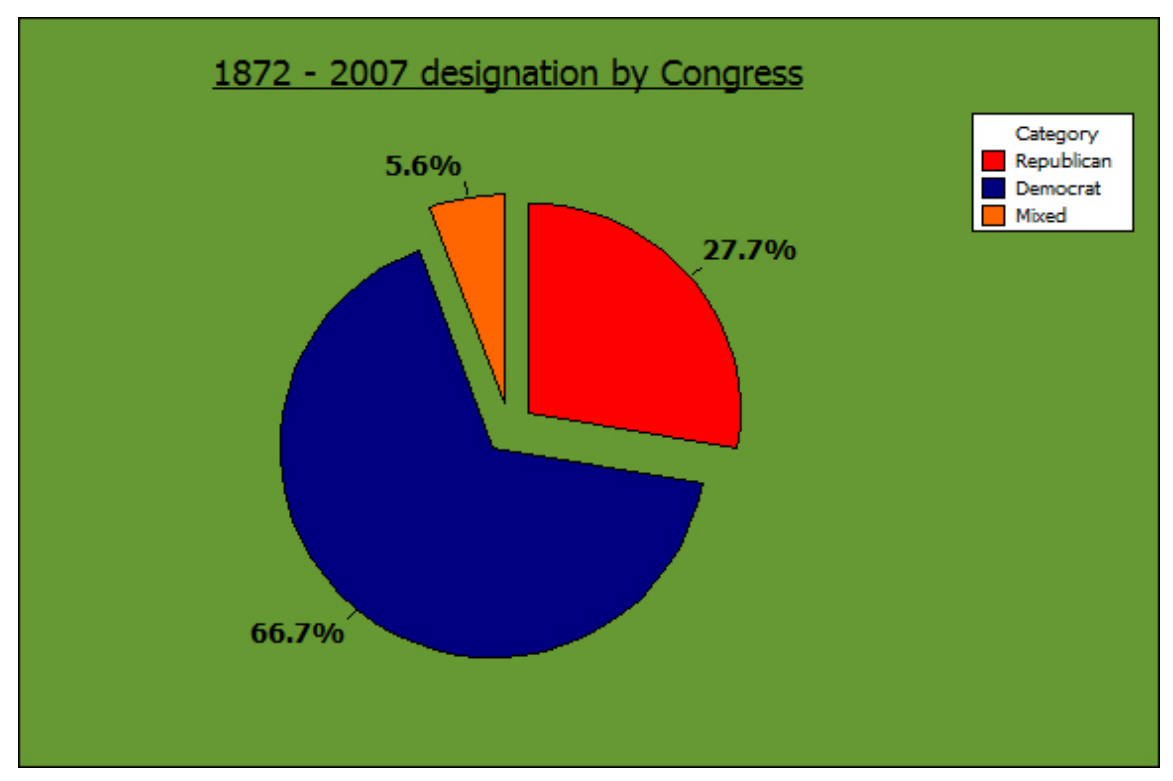

Graph 10 shows that $66.7 \%$ of the National Park units have been designated by a

Democratic majority in Congress. While this finding is not significant in its self, when compare to Graph 9, it shows that the political affiliation of the Congress effects designation more. The data displays in graph 10 reveals that having a Democratic majority in Congress will create an increase of National Park unit designations and that a designation is $33.3 \%$ or $1 / 3^{\text {rd }}$ more likely to occur over another ruling party. 
Graph 11. Time line of all designation

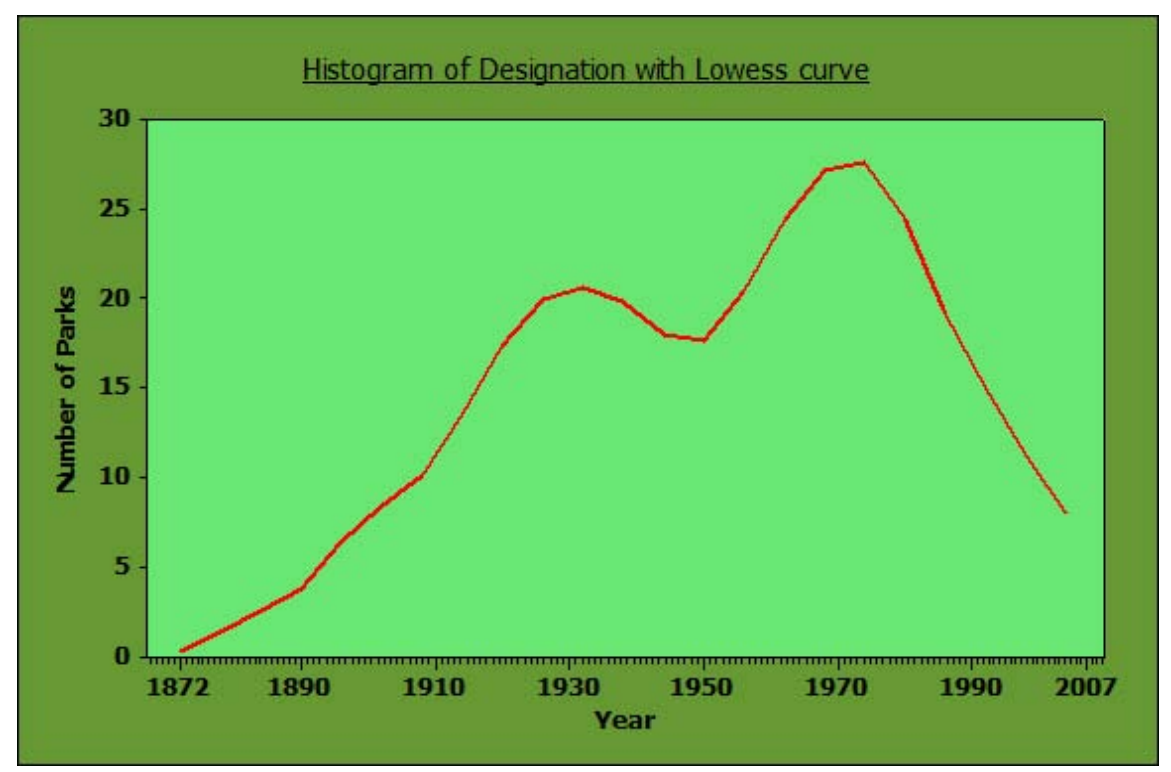

Graph 11 displays the timeline of all designations from 1872 to 2007 . There are two visible peaks and an obvious slow rise from 1872 to the 1930's and a slow drop from the mid 1980’s to 2007. The first peak could have occurred because of the 1933 transfer of military battlefields, forts, and monuments from the War Department to the National Park. The first peak also may have occurred because of the New Deal and putting people back to work building parks and other infrastructure (Johnson, 1915). Most likely it is a combination of the two that has caused the first peak. If this is taken out a less noticeable peak as well as a less noticeable valley would have occurred in that time span. The peak in the 1970's most likely occurred because of the environmental and preservation policies that were taking place in that decade such as the National Historic Preservation Act of 1966 (NHPA) and the National Wild and Scenic River Act of 1968. 


\section{Exploration of themes}

The next set of graphs focus on National Parks before 1923, in the west and are associated with railroad land grants. This analysis was to see if there was a correlation between the designation of a National Park unit and the construction of a railroad. 1922 was chosen as a cutoff point because the automobile became more common in this era and visitation to National Park units via this mode of transportation increased dramatically according to Yard (1922)

Graph 12. Time line of designation between $1872-1922$ in the west

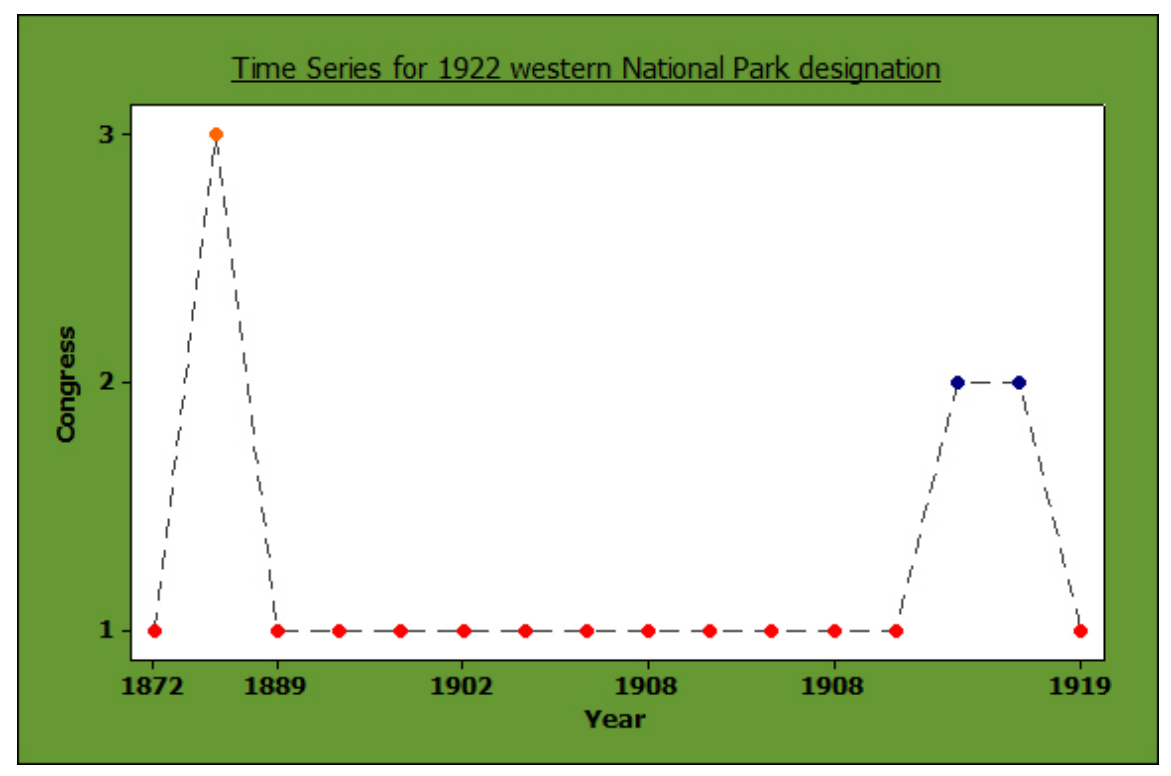

***1 - Republican, 2 = Democrat, 3= Mixed congressional majority

This timeline reveals that between the years of 1872 to 1919 only two National Park units were designated by a democratically controlled Congress that were located in the west and was intersected by a railroad grant. Between the years of $1872-1922$ there was almost a 50\% split in the majority that controlled Congress (Biographical Directory of the United States Congress 
1774 - present). So this would lead one to believe that since $81 \%$ of these parks were designated when Republican representation was in control, that they may have been more receptive to lobbyists.

Graph 13. Pie chart of designation between the years of $1872-1922$ in the west

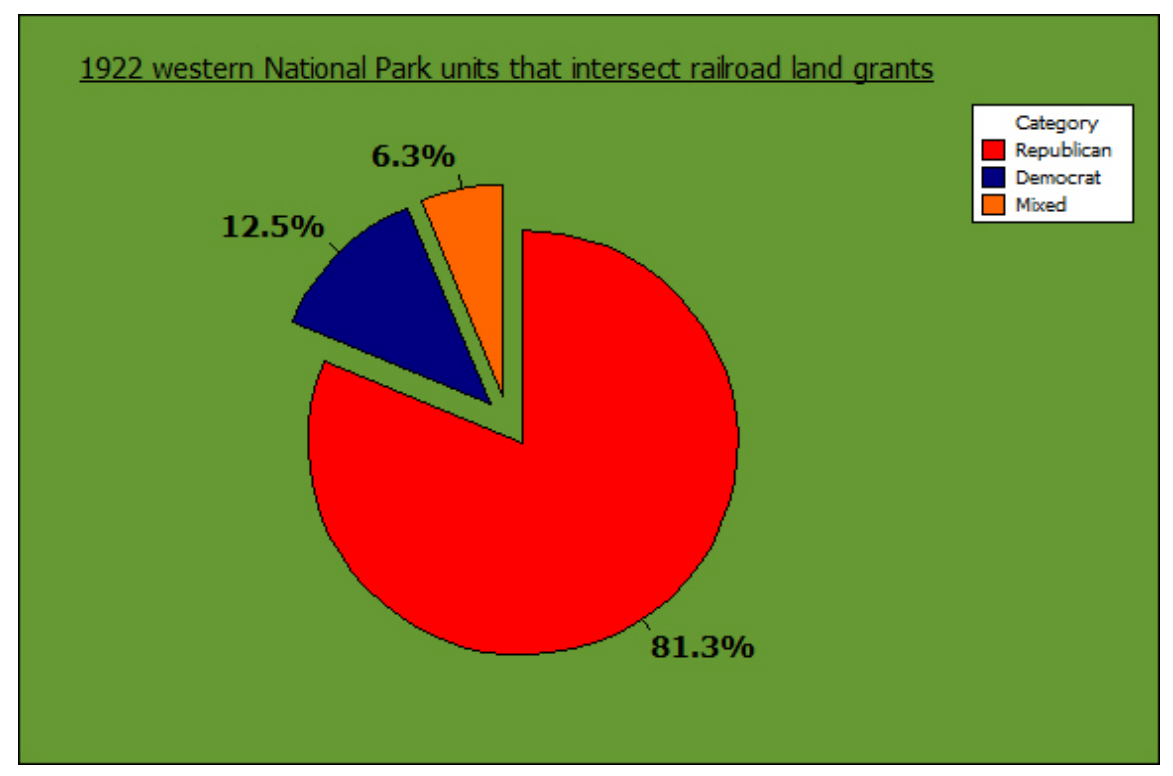

Graph 13 shows a strong correlation, $81.3 \%$ of the designations in the pre 1923 west that intersect railroad land grants were designated by a republican controlled congress. The $12.5 \%$ for the Democrats were National Monuments and designated after the Antiquities Act of 1906. If those are taken out of the equation $93.8 \%$ of the parks were designated during Republican control. 
Graph 14. Matrix plot of cooperation between Congress and the President between the years of 1872 - 1922 in the west with parks that correlate with the railroad land grants

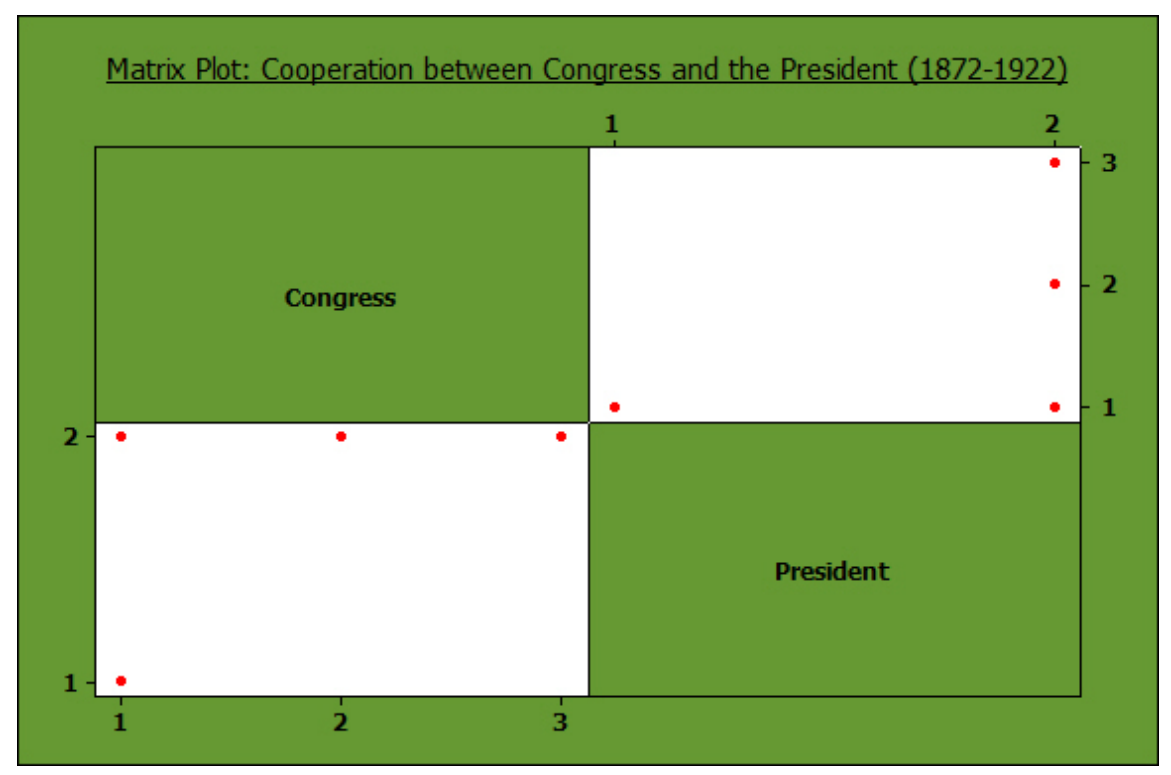

***1 - Republican, 2 = Democrat, 3= Mixed congressional majority

This is a supplemental way to plot the prior graph (graph 12). This is known as a matrix plot. A "matrix plot allows you to assess relationships among several pairs of variables at once by displaying an array of small scatter plots on a single screen” (Joiner, Ryan, \& Ryan, 2005, p. 162). It shows how during this time span a Republican President never designated a National Park unit with either a Democratic Congress or a mixed Congress. The data does show cooperation by a Democratic President. As stated earlier that the majority control of Congress between these dates were almost a 50\% share of control of the Congress. 
Graph 15. A regression for predicting the President’s political affiliation via the congress political affiliation from all data (1872 - 2007).

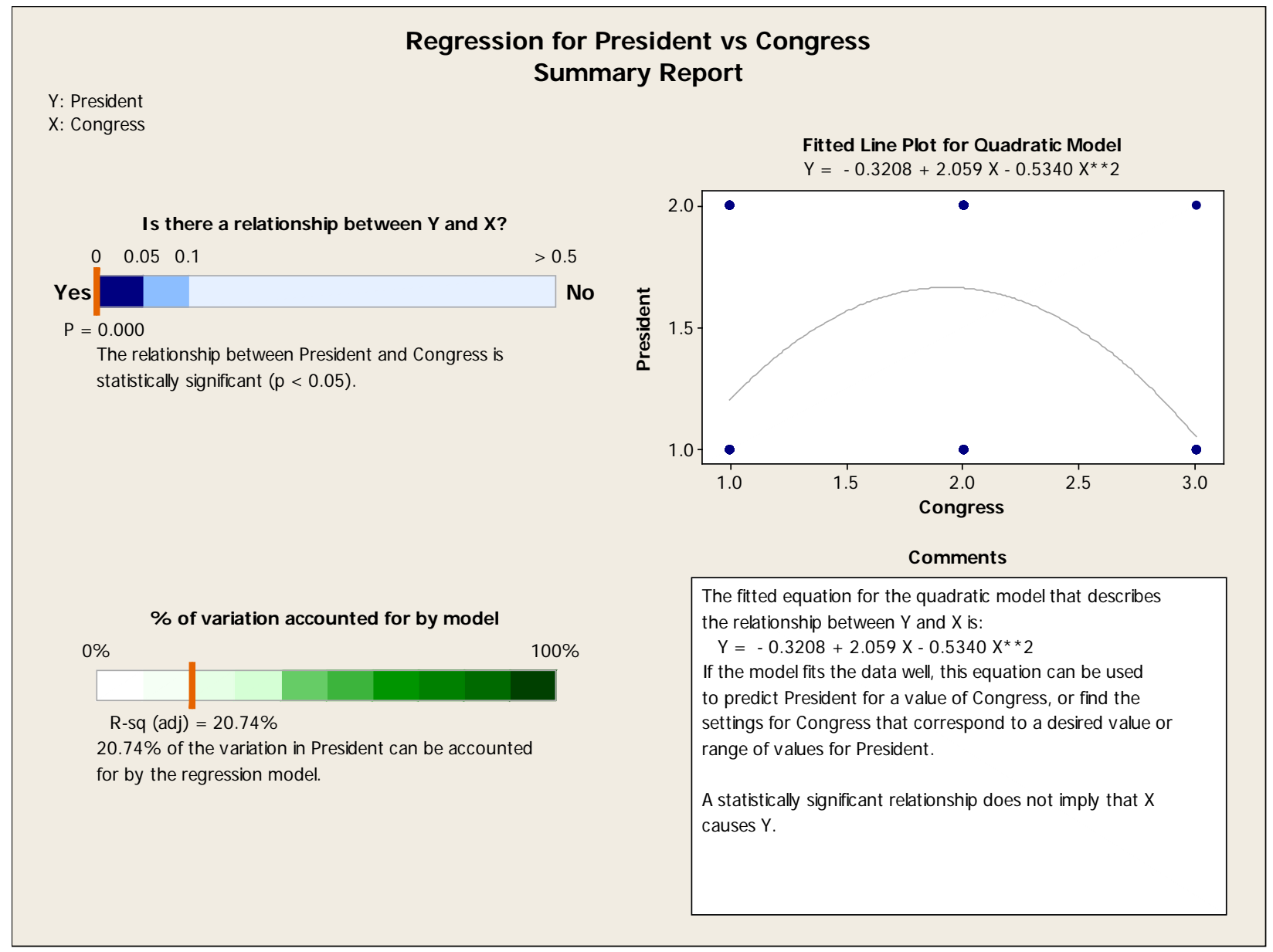

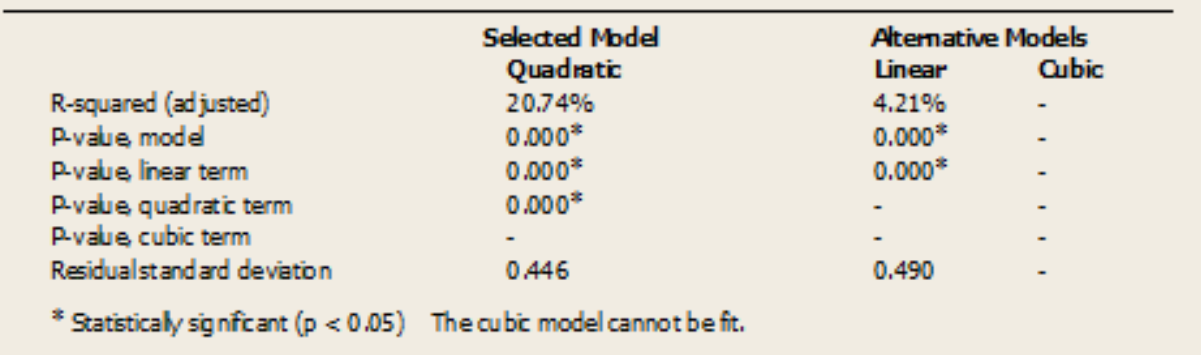

This regression analysis shows that it may be possible to predict the Presidents political affiliation via the political affiliation that has the majority control of congress during the years of a National Park unit designation. The relationship between the political affiliation of Congress 
and of the Presidency is statically significant $(\mathrm{P}<0.05)$. The input data into this regression calculation was the data from 1872 - 2007 that contains 354 data points, which is large enough to predict effectively.

Graph 16. A regression for predicting the Congress political affiliation from the designated National Park’s simplified designation from all data (1872 - 2007).

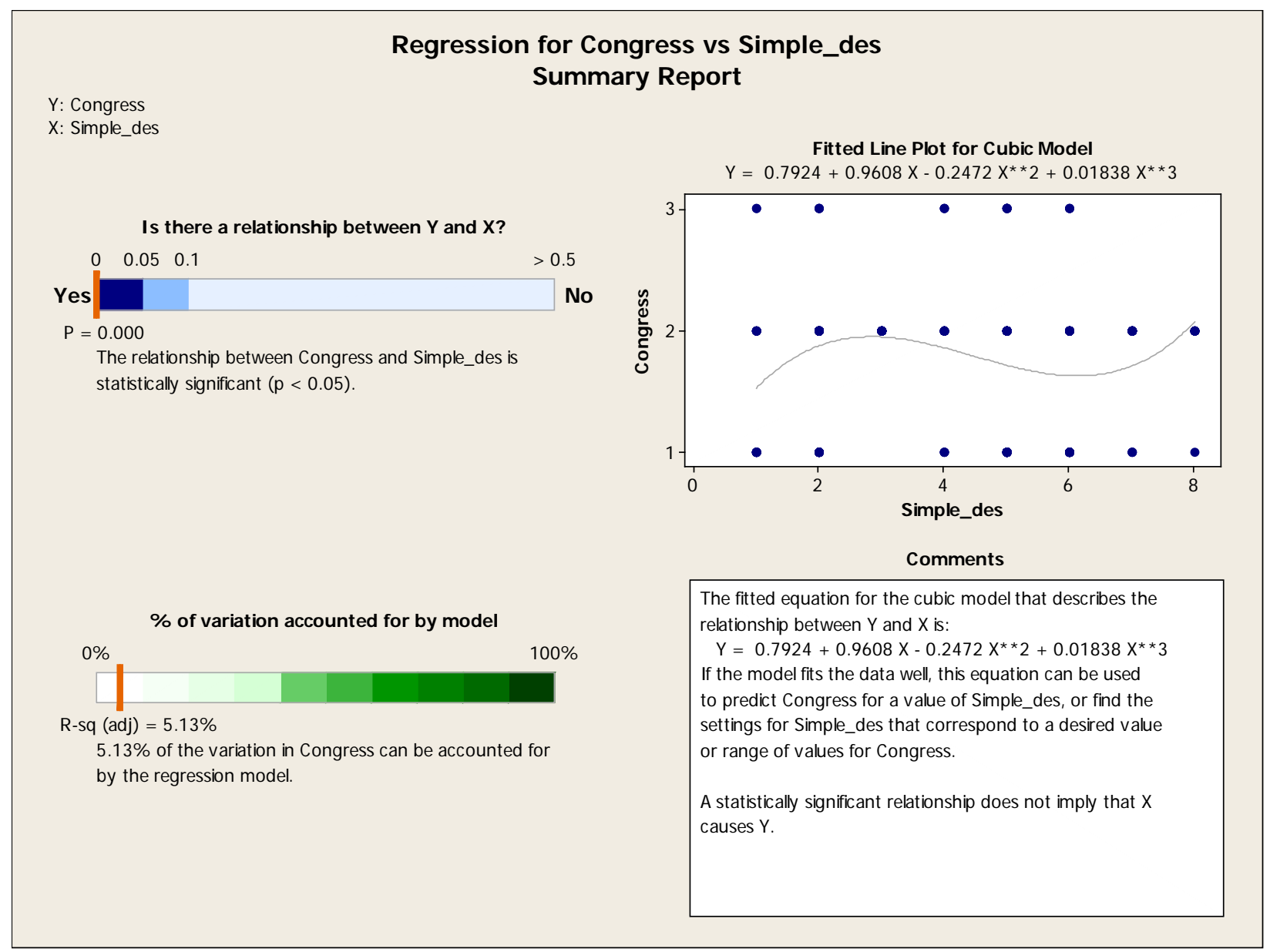




\begin{tabular}{lcll} 
Statistics & & \\
\hline & $\begin{array}{c}\text { Selected Model } \\
\text { Cubic }\end{array}$ & \multicolumn{2}{c}{ Alternative Models } \\
Linear & Quadratic \\
R-squared (ad justed) & $5.13 \%$ & $0.00 \%$ & $0.00 \%$ \\
P-value mode & $0.000^{*}$ & 0.327 & 0.615 \\
P-vaue linear term & $0.000^{*}$ & 0.327 & 0.934 \\
P-value quadratic term & $0.000^{*}$ & - & 0.908 \\
P-value cubic term & $0.000^{*}$ & - & - \\
Residualstandard devation & 0.521 & 0.534 & 0.535 \\
* Statisticaly signfcant $(\mathrm{p}<0.05)$ & & &
\end{tabular}

This regression analysis shows that it may be possible to predict the congressional majority's political affiliation from the value of the simplified description. The relationship between the political affiliation of Congress and of the simplified description is statically significant $(\mathrm{P}<0.05)$. The input data into this regression calculation was the data from $1872-$ 2007 that contains 354 data points, which is large enough to predict effectively. The designations were simplified into eight designations and are: $1=$ Military, $2=$ Historical, $3=$ Water related, $4=$ Memorial, $5=$ Monument, $6=$ National Park, $7=$ Recreation, $8=$ Park. 
Map 4. The distribution of all National Park units from (1872 - 2007).

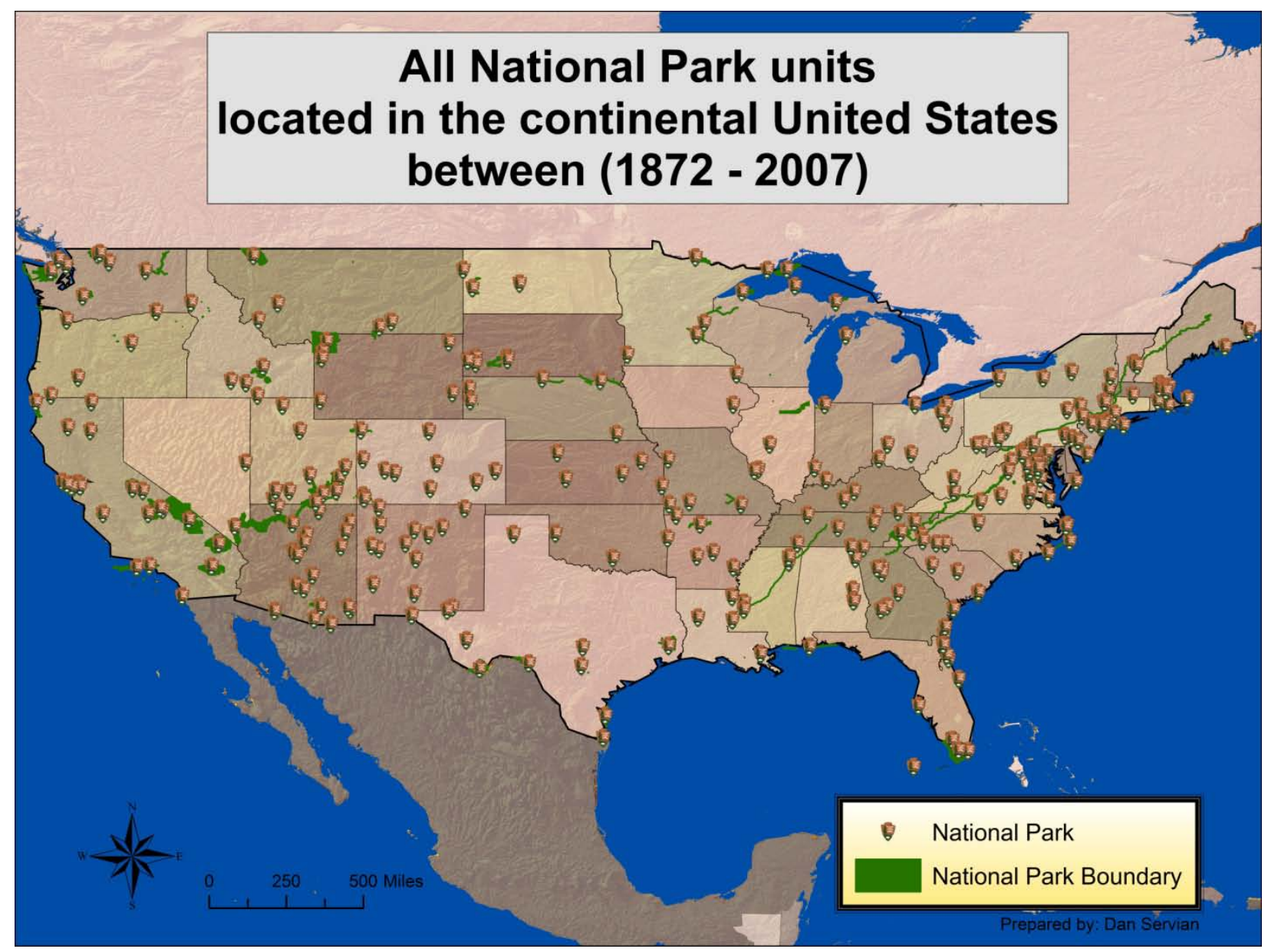

This shows the distribution of every national park in the continental United States between the years of $1872-2007$. You can make out some clusters in: the corridor from Washington D.C. north to Boston, San Francisco, South Florida, and the four corners area. 
Map 5 - 9. Shows the correlation between the railroad land grants and the formation of National Park units.

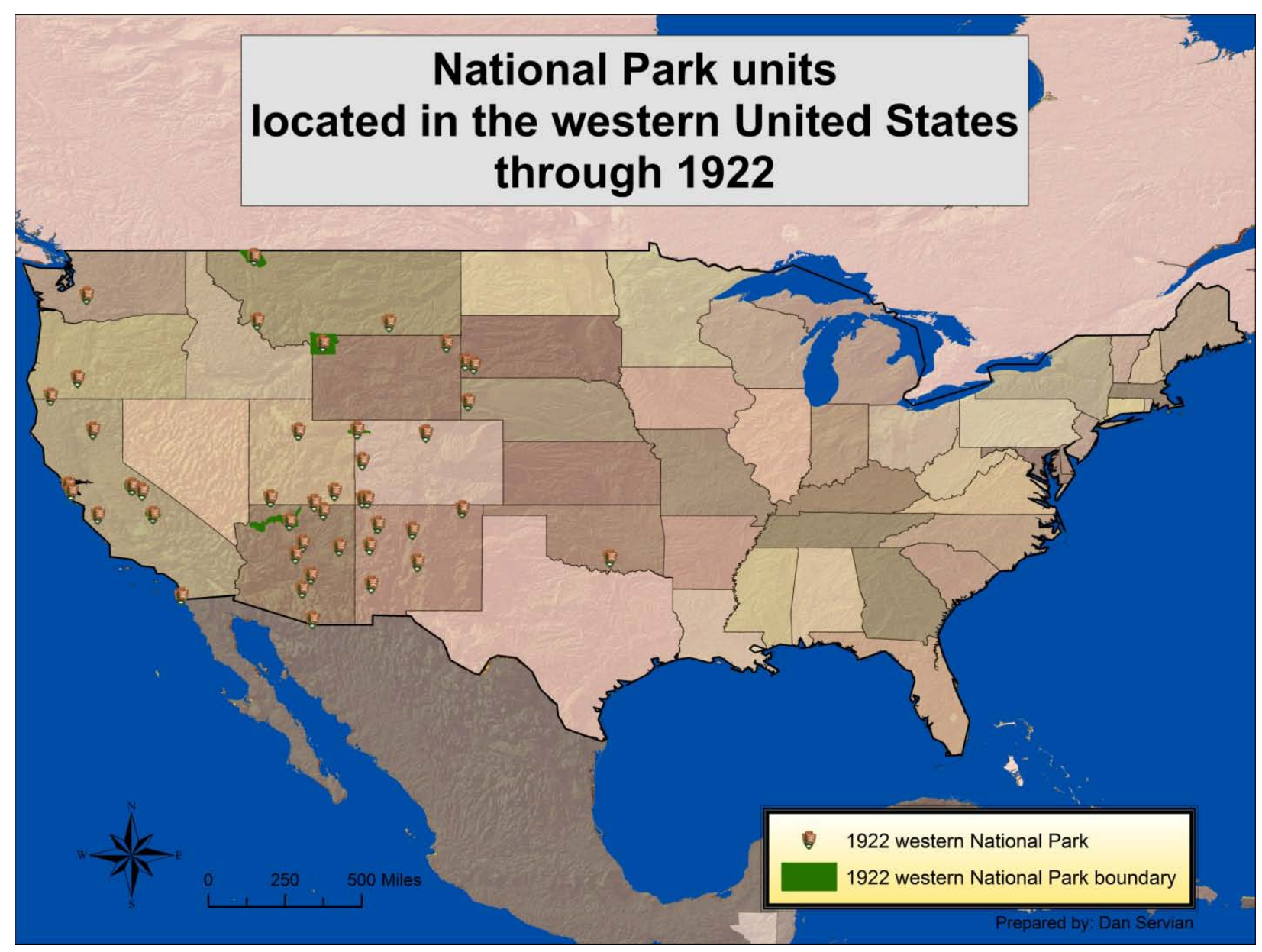


Map 6. Western National Park units pre 1923 with railroad land grants

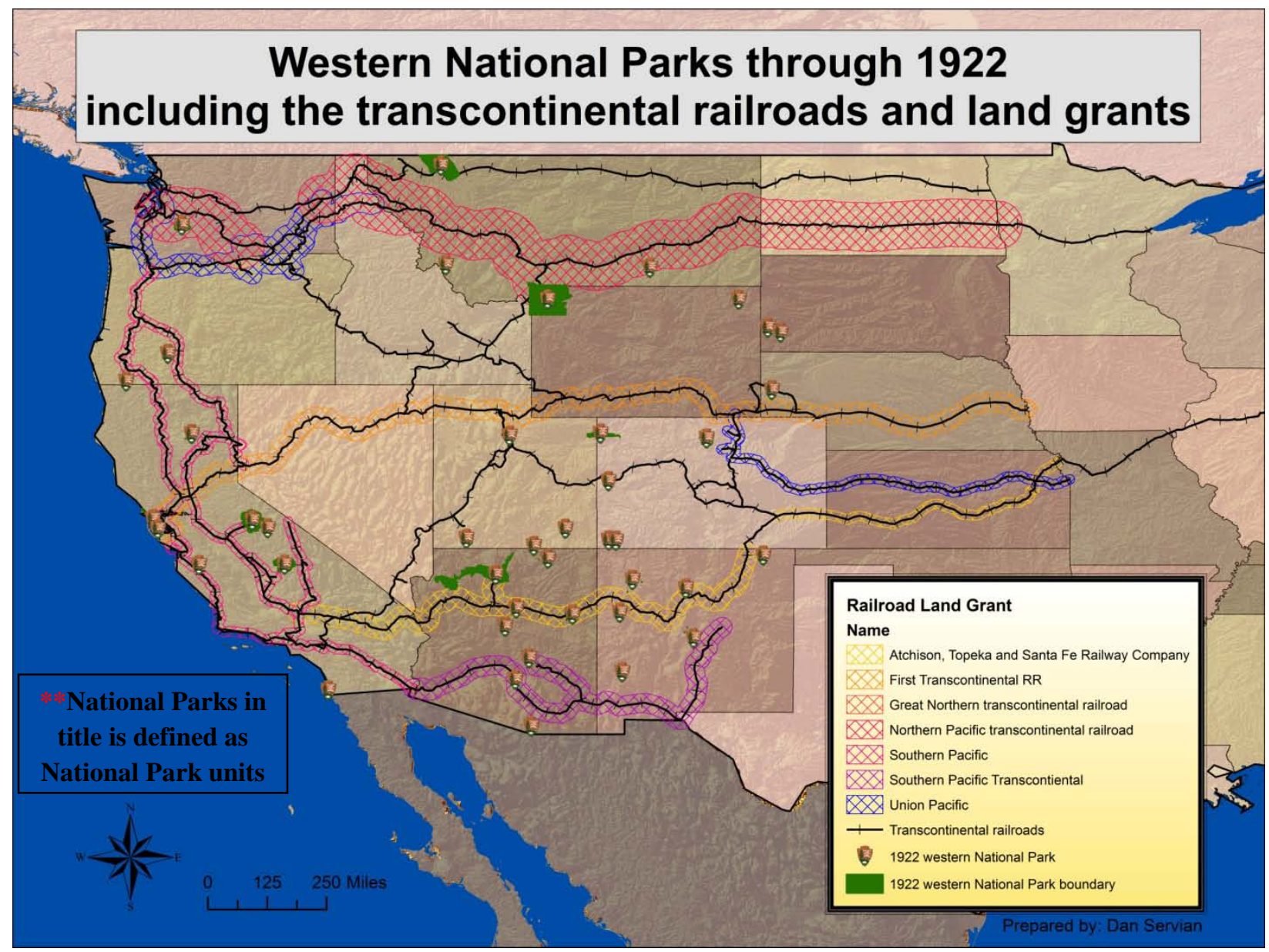


Map 7. The National Park units pre 1923 in the west the reside within the land grants of the railroads

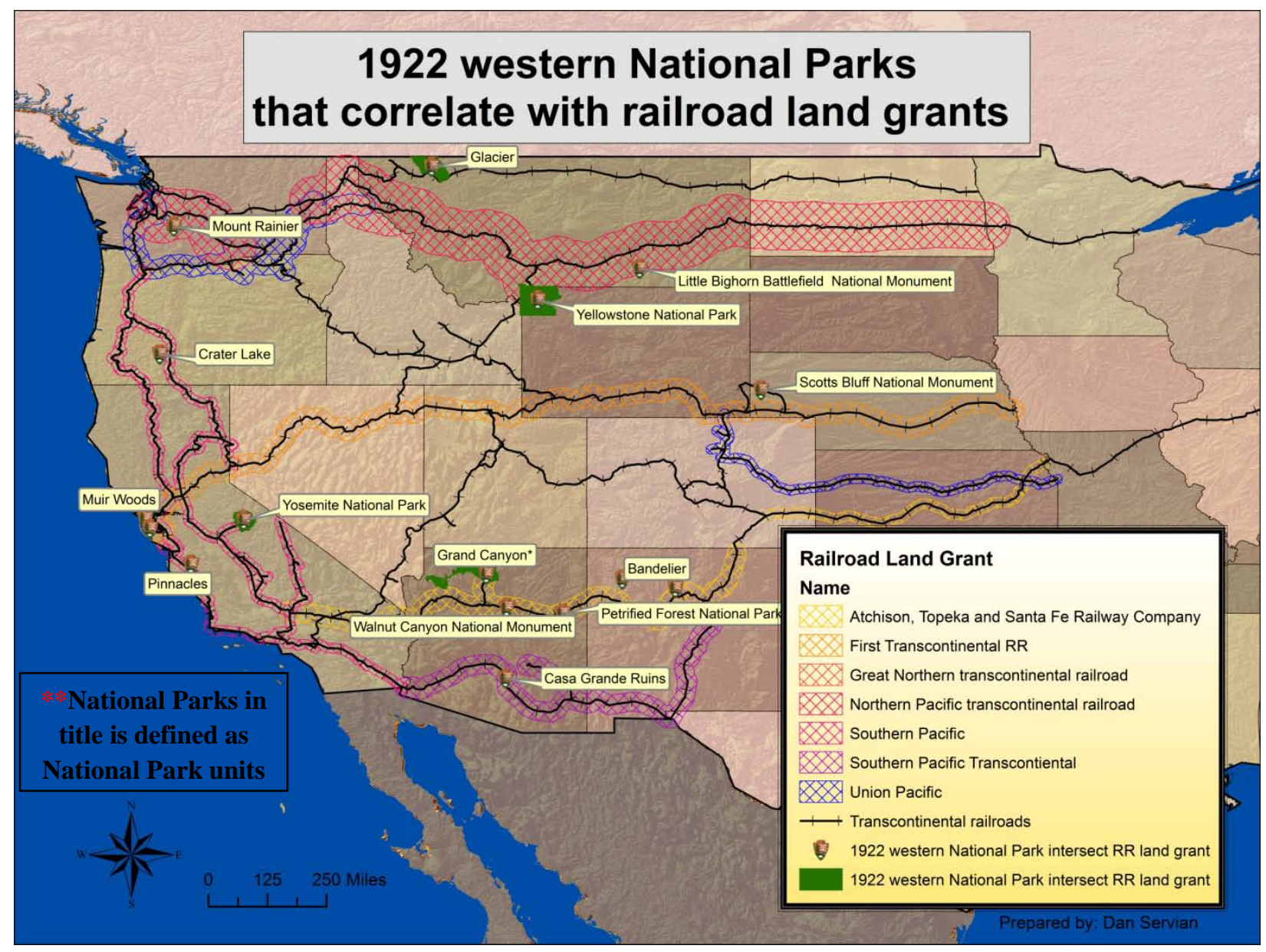


Map 8. National Park units that intersect the railroad land grant with a 100 mile buffer

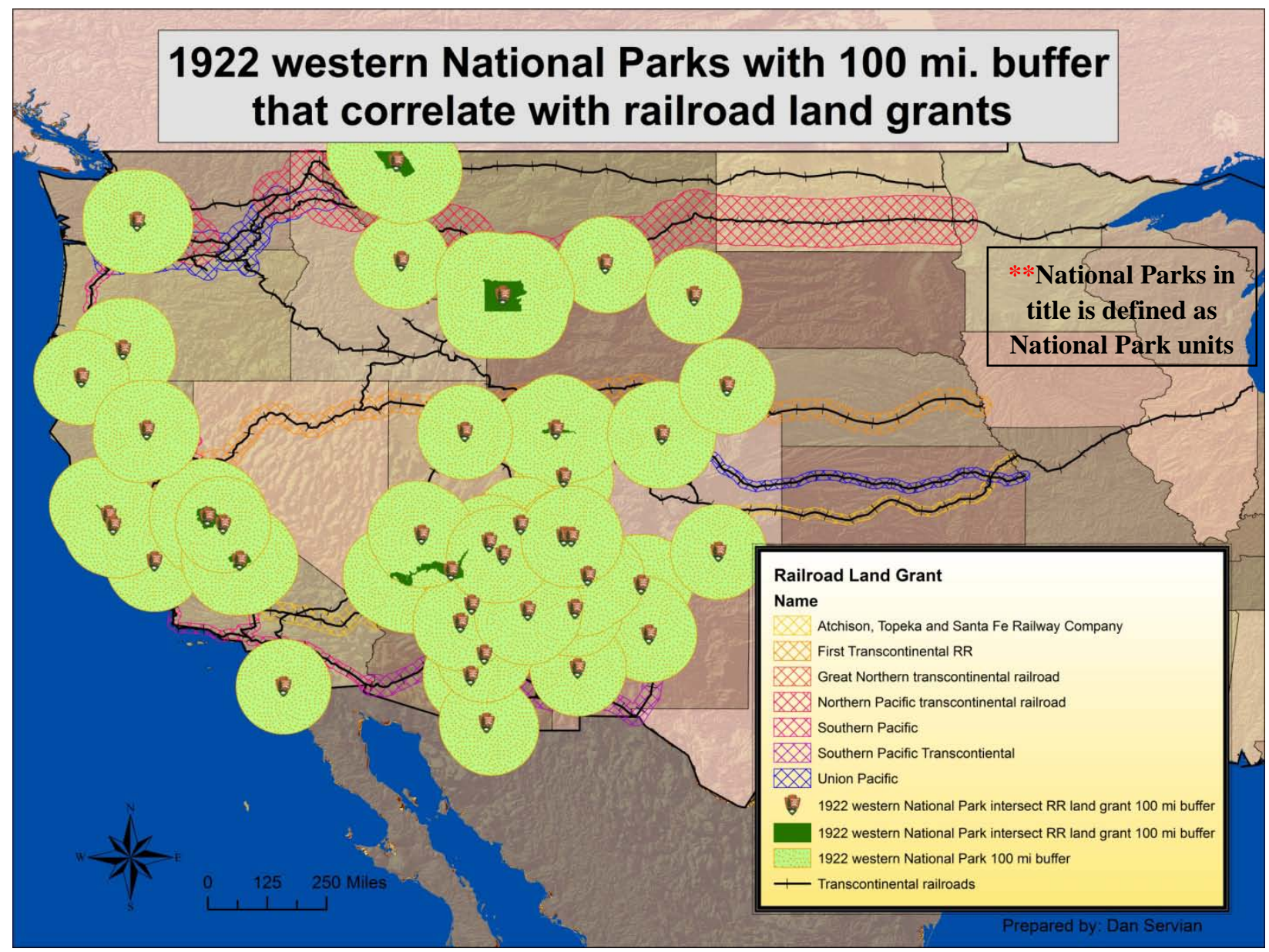

Maps 5 through 8 show the National Park units of the west pre 1923 and the correlation between them and the railroads. There are a total of 40 National Parks located in the west pre 1923. Out of the 40 National Park units located in the west pre 1923, 16 of the units are located within the land grants awarded to the railroads. Despite the fact that only $40 \%$ of the western pre 1923 National Park units were located within the boundary of the railroad land grants these parks accounted for $83 \%$ of the total acreage of the western pre 1923 units. When a buffer of one hundred miles is placed over the western pre 1923 National Parks, all 40 or 100\% reside within 100 miles of a land grant. The 100 mile buffer was calculated because according to Stynes (2006) the impact of a National Park in the western states can be as much as 100 miles. The 
rationale is that railroads would build towns along their route and these National Park units must have had an impact on them.

Map 9. The association between major battles fought on United States soil and the number of military designated National Park units

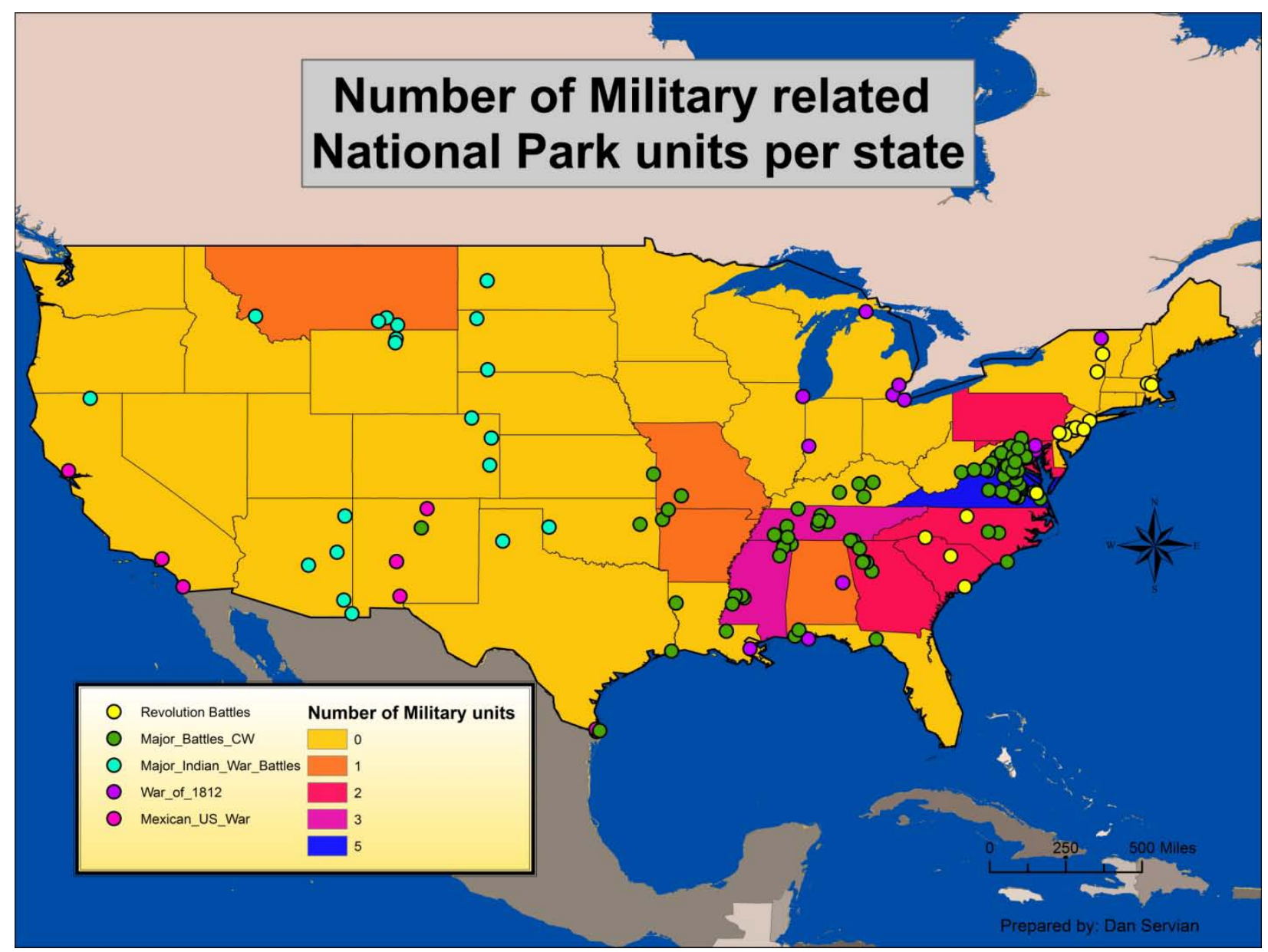

Map 9 shows the distribution of military designated National Park units associated with major battles fought in the United States. Just under half of the military designated National Park units or 12 out of 25 are military designations that are associated with the Civil War. The major battle data contains 157 points of those points 98 (62\%) are from the Civil War. Upon further investigation, many more of the major battles have been protected but not designated as a 
National Park military unit. Forty one of the major battle points were located within National Park unit boundaries, albeit 29\% are Civil War related. For instance, many of the protected sites associated with the Indian Wars are protected as Monument or Memorials. Typically these sites contained archeological significance but also happened to be where the battles took place. The same is for many of battles of the War of 1812. While only one of the battles from the War of 1812 is designated as military, a total of six of the battles are protected. Interestingly the data from the War of 1812, only two of the protected six are not associated with shoreline.

Map 10. National Park units that intersect streams or shore

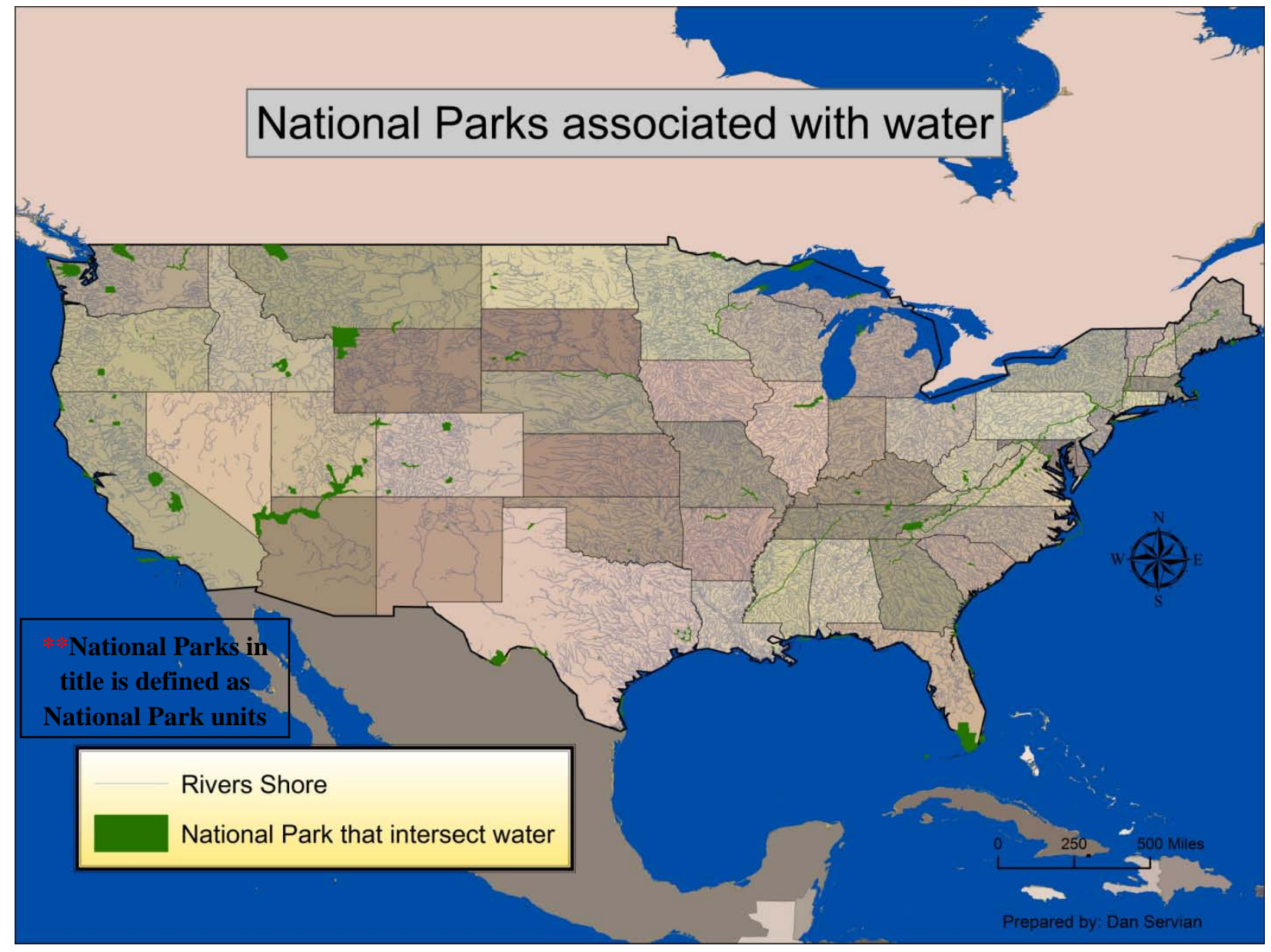


Out of 354 National Park units in this study, unexpectedly only 167 intersect stream or shore. In this study a stream was a water body that had a hydrological code of three or lower. This coding system was created by the United States Geological Survey. A code of three is equal to a stream that is at the basin level and was the minimum for inclusion in this analysis. One would postulate that most of the National Park units would intersect at least a major tributary. National Park units that intersect a water body account for 19,771,176 acres while the total for all National Park units is 27,227,707 acres. Locations that insect water only accounts for $47 \%$ of the total number of parks, yet account for $73 \%$ of the total acres. This shows that most of the National Park units are relatively small. The National Park units that associated with water are typically designated: National Recreation Areas, National Seashores, National Rivers, National Historic places, Memorial Parkways, or National Parks. 
Map 11. National Park units that associate with Federal Lands

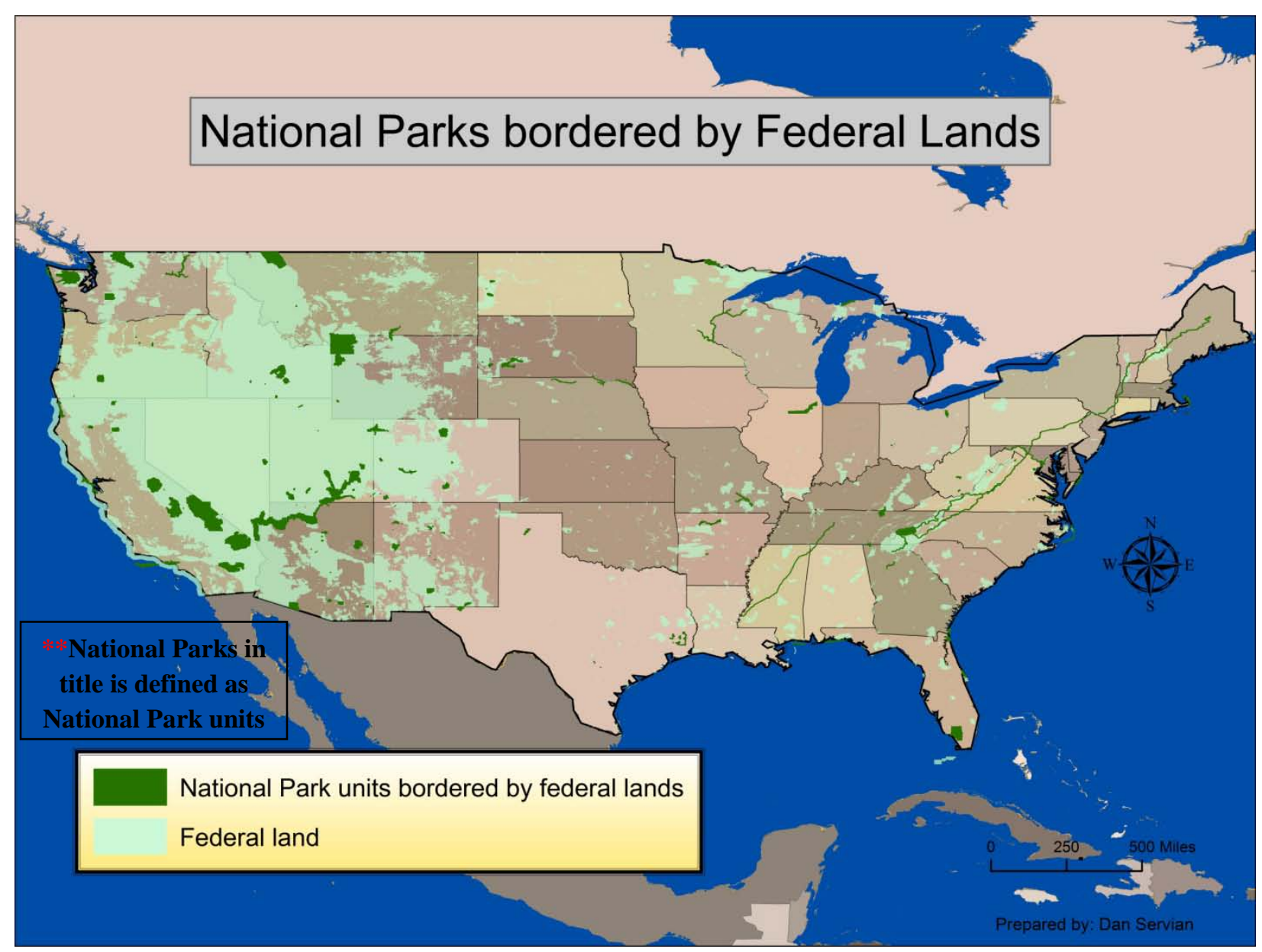

This map shows the association of National Park units and the land that is controlled by the government. There are a total of 140 National Park units that are associated with the federal layer. Unfortunately, this dataset is missing areas that are not surrounded by federal lands. The only available dataset that displayed federal lands had the National Park Service as one of the land holders. To compute this dataset, the National Park federal lands were omitted because one could not tell if these lands were federally controlled before designation. 
Map 12 National Park units associated with all variables

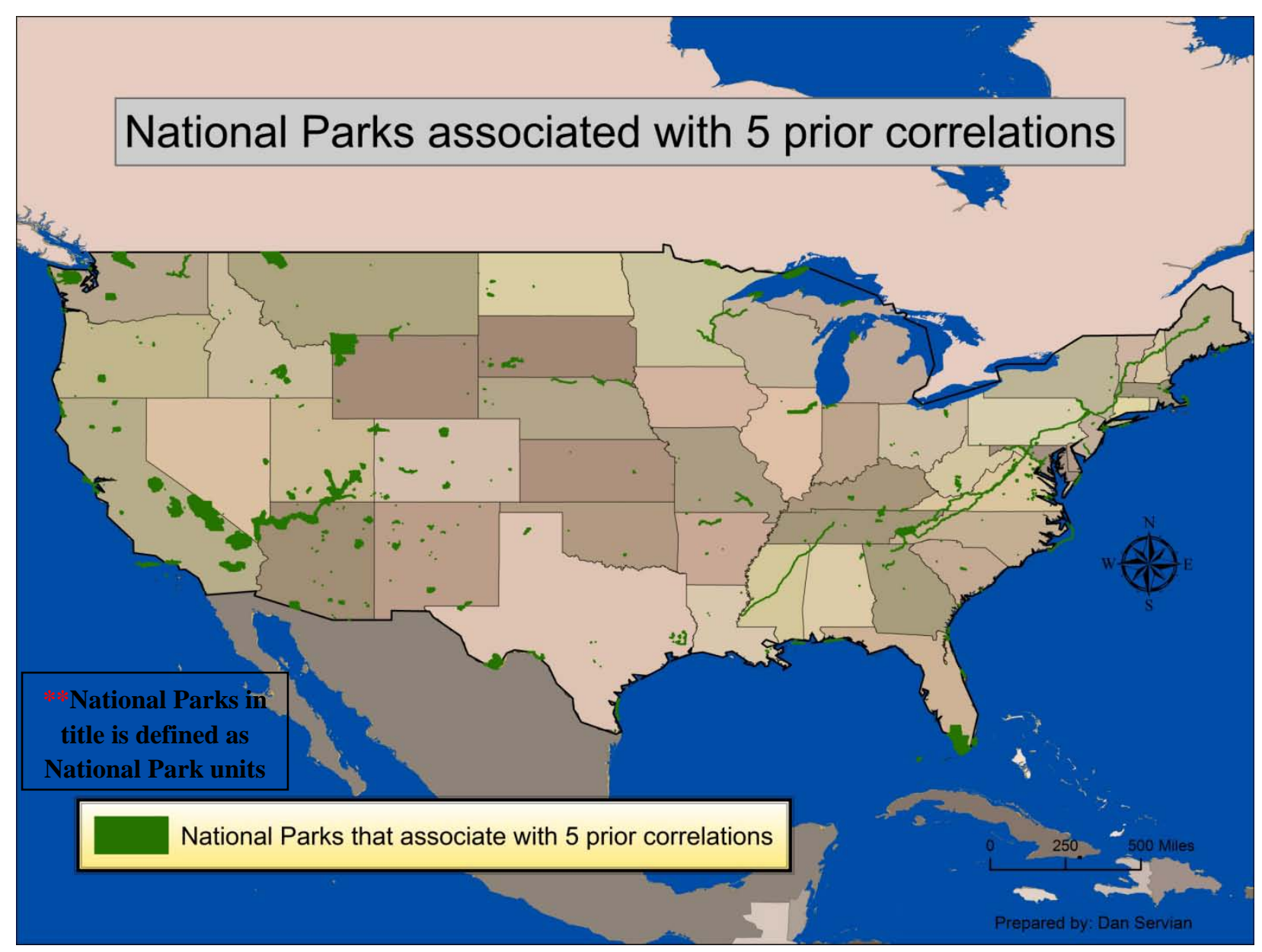

Map 12 is the culmination of the prior map out puts. This map represents National Park units associated with: railroad land grants, major military battles, stream and shores, border federal lands, and the National Historic Register. The National Historic Register map was not shown. This was because the file was not visible at this map scale. To create this output, each National Park unit that correlated with one of the prior (Map 7, 9, 10, 11) 5 GIS theme layer was merged onto one map. These variables represent 288 or $81.3 \%$ of every National Park unit in the continental United States. These National Park units also represent 27,186,195 acres out of 27,227,707 which is $99.8 \%$ of all National Park acreage. 
The following analysis is of spatial autocorrelation. The analysis looks at both bivariate and univariate analysis. All significant correlations are shown.

\section{ESDA results}

Map 14. Univariate LISA 2007 Population

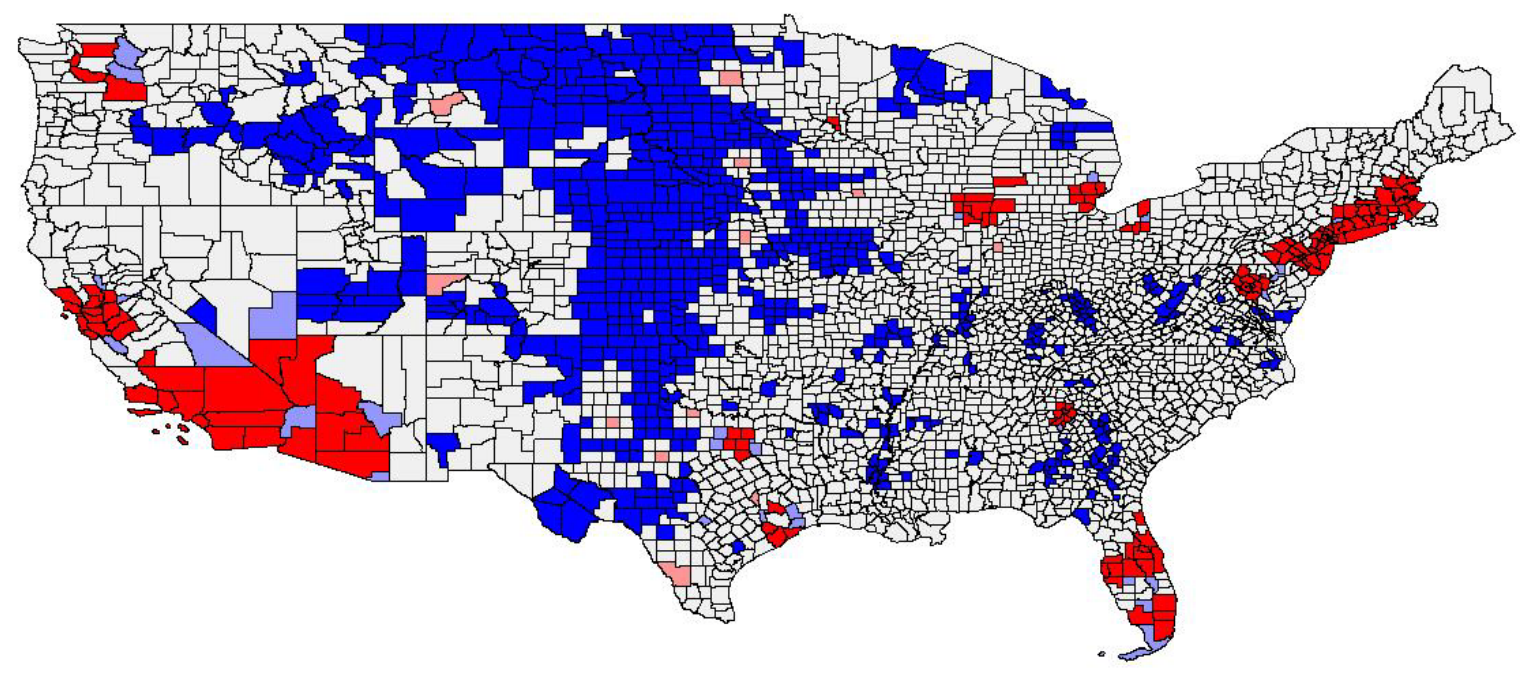

Red $=$ High - High cluster $\quad$ Blue $=$ Low - Low cluster

This univariate LISA map displays clusters of population per county. The bright red shows a statistically significant (p value 0.05 ) cluster of counties with high population. The dark blue highlights statistically significant ( $\mathrm{p}$ value 0.05 ) clusters of counties with low population. To establish as a cluster in a LISA analysis, a county needs to be neighbored by similarly populated counties. For example, if county A touches the boundary of another county that has an opposite population value, than county $\mathrm{A}$ is not displayed in a bright color. But, if county $\mathrm{A}$ is 
neighbored by counties with all similar populations, then county A will be highlighted in a bright color. The bright blue seen in the middle of the country is a cluster of counties with a low population. Map 14 illustrates numerous bright red clusters that signify areas that have a high population. You can make out the bright red of the corridor from Washington D.C. north to Boston, interstate 4 (Orange expressway) in Florida and counties in southern California.

Graph 17. Moran’s I with P-Value for 2007 population

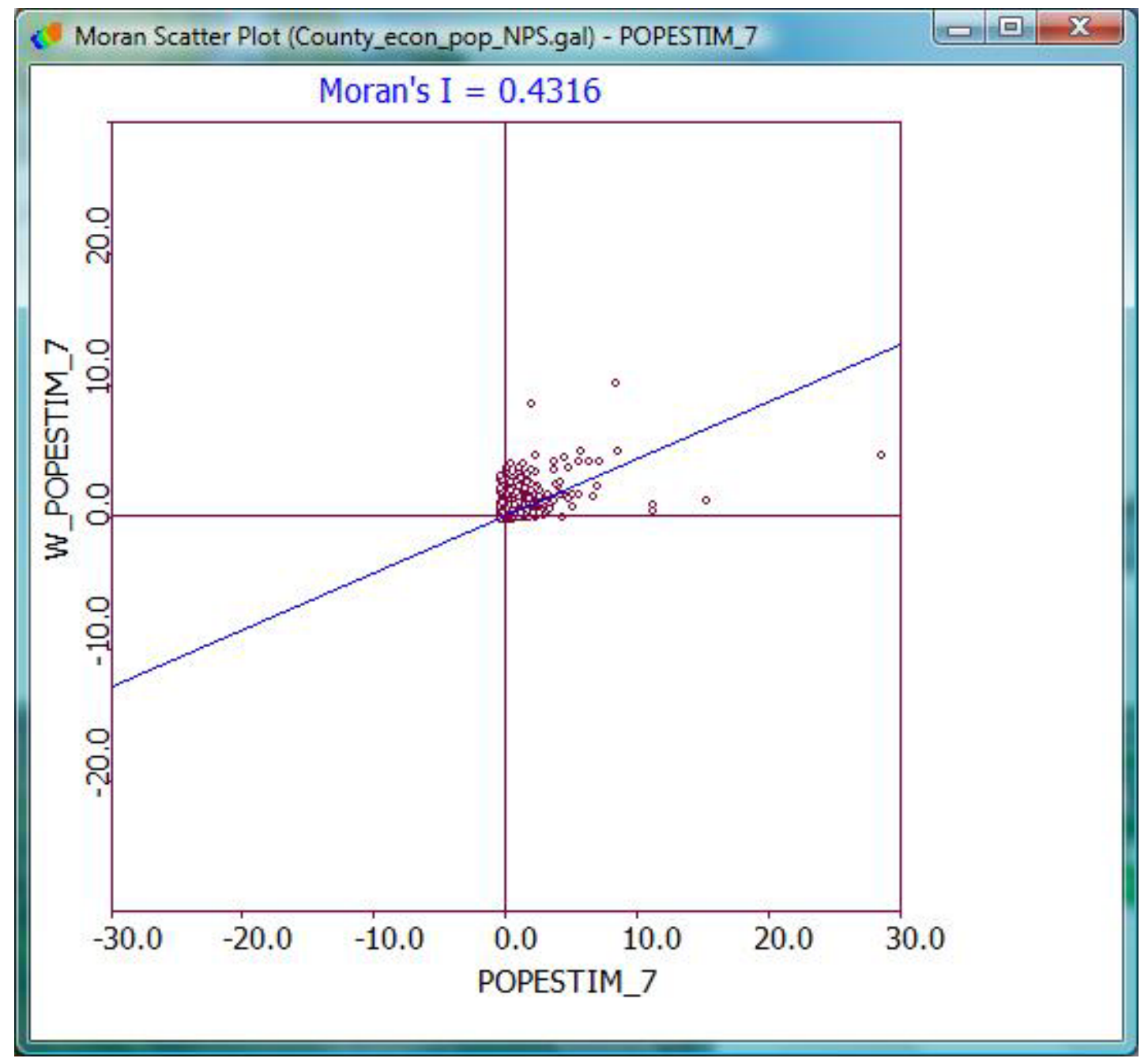




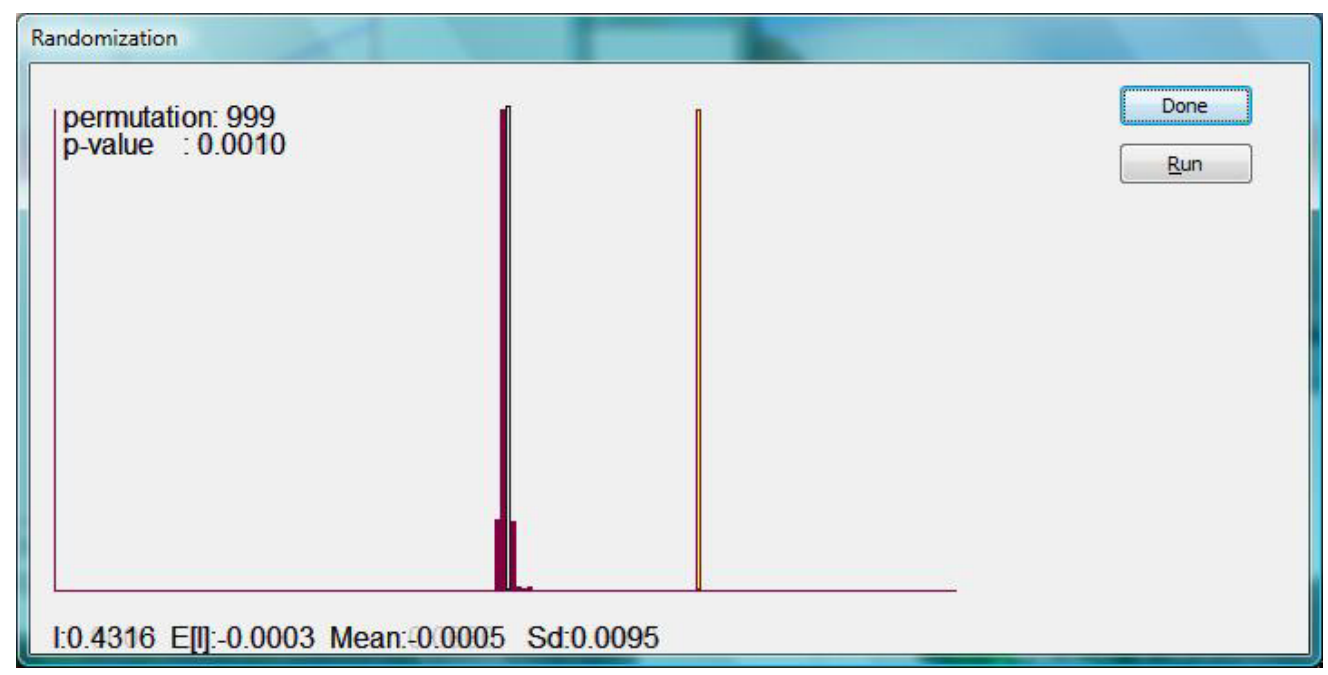

Graph 17 shows a very significant and predictable population dataset and thus not random. The data across the entire country is positively correlated. The data was run to 999 permutations and is shown as statistically significant. Moran's I analyze data spatially across the entire country regardless of local neighbors and looks for a strong autocorrelation in the dataset. When running a spatial autocorrelation test, a researcher is looking for areas that have higher or lower rates of occurrence that would not happen because of chance (Fotheringham, 1992). Significant special autocorrelation allows the researcher to use the dataset for predictions. 
Map 15. A LISA analysis of the simple designation description

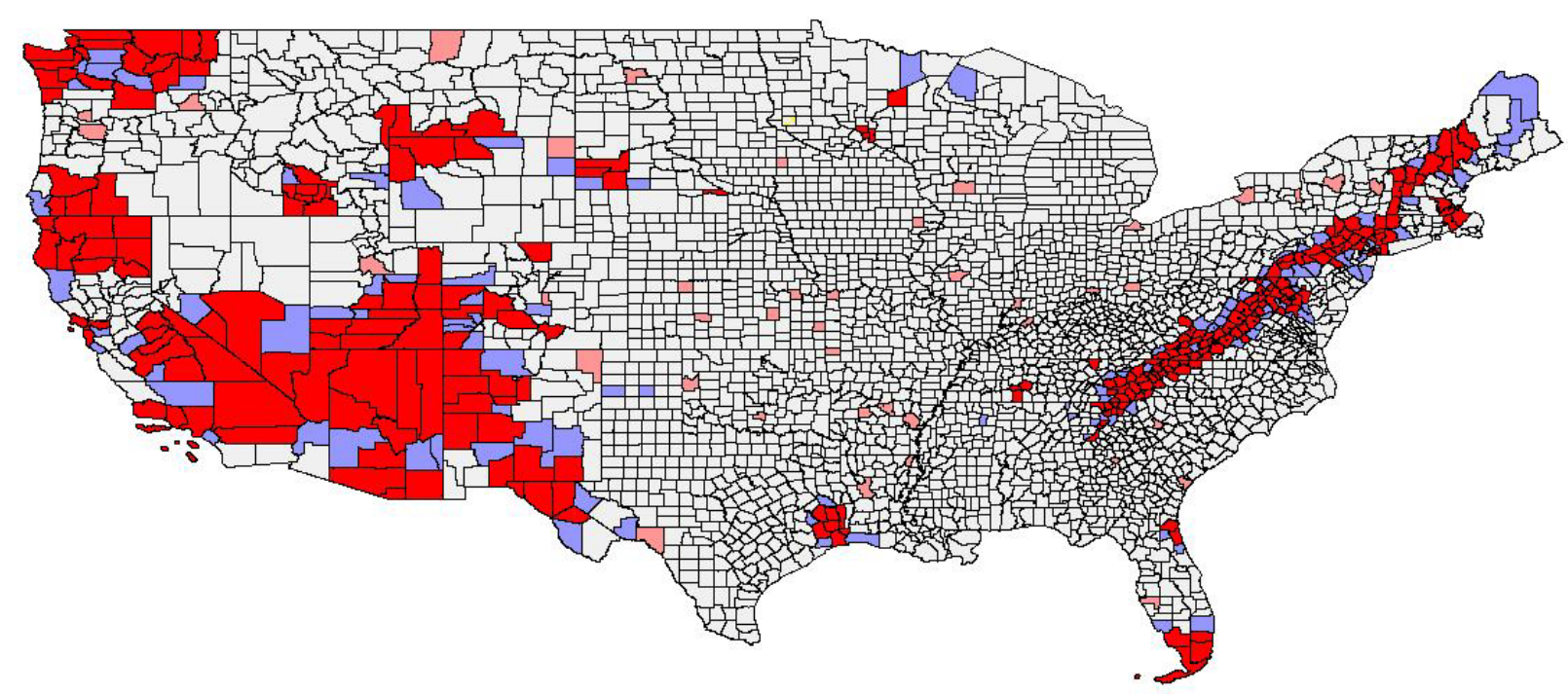

This map shows many local or neighboring high - high clusters that signify similar designations that are located near each other. This analysis investigated the simplified National Park unit designation description, such as historical or water, and looked for significant clusters or groupings of them. The goal of running this analysis was to see if there were clusters of National Park unit designations at the county level. The Appalachian Trail shows up very well in this analysis and would be an obvious cluster when looking at the data locally because this unit traverses many counties that are neighboring. Significant local autocorrelation can also be observed at the Four Corners, the Sierra Nevada Mountains, and Cascade Range. In addition to the Four Corners and the three mountain ranges, major population centers can be viewed as positively autocorrelated. Boston, Washington D.C., San Francisco, Los Angeles, Jacksonville, and south Florida all show up as a high - high cluster which designates clusters of similarly designated National Park units. 
Graph 18. Moran’s I with P-Value for simple designation description
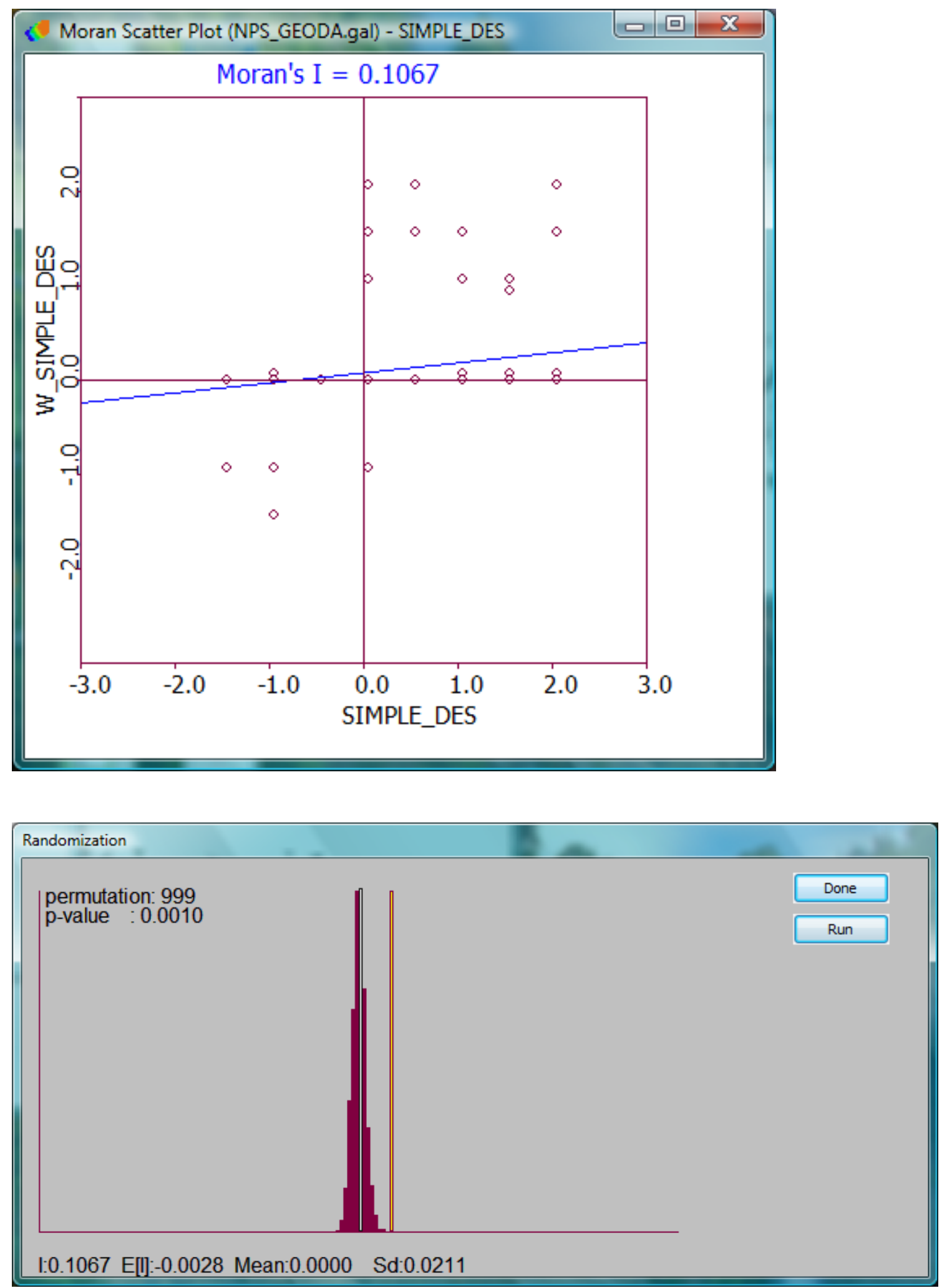
The analysis of Moran's I for simple description of designation shows up well and is highly significant. The data was permutated 999 times. Graph 18 as well as the prior LISA and Moran’s I table support Tobler’s (1970) first law of Geography states "everything is related to everything else, but near things are more related than distant things” (p. 237).

Graph 19. Getis-Ord G of National Park Simple designation description

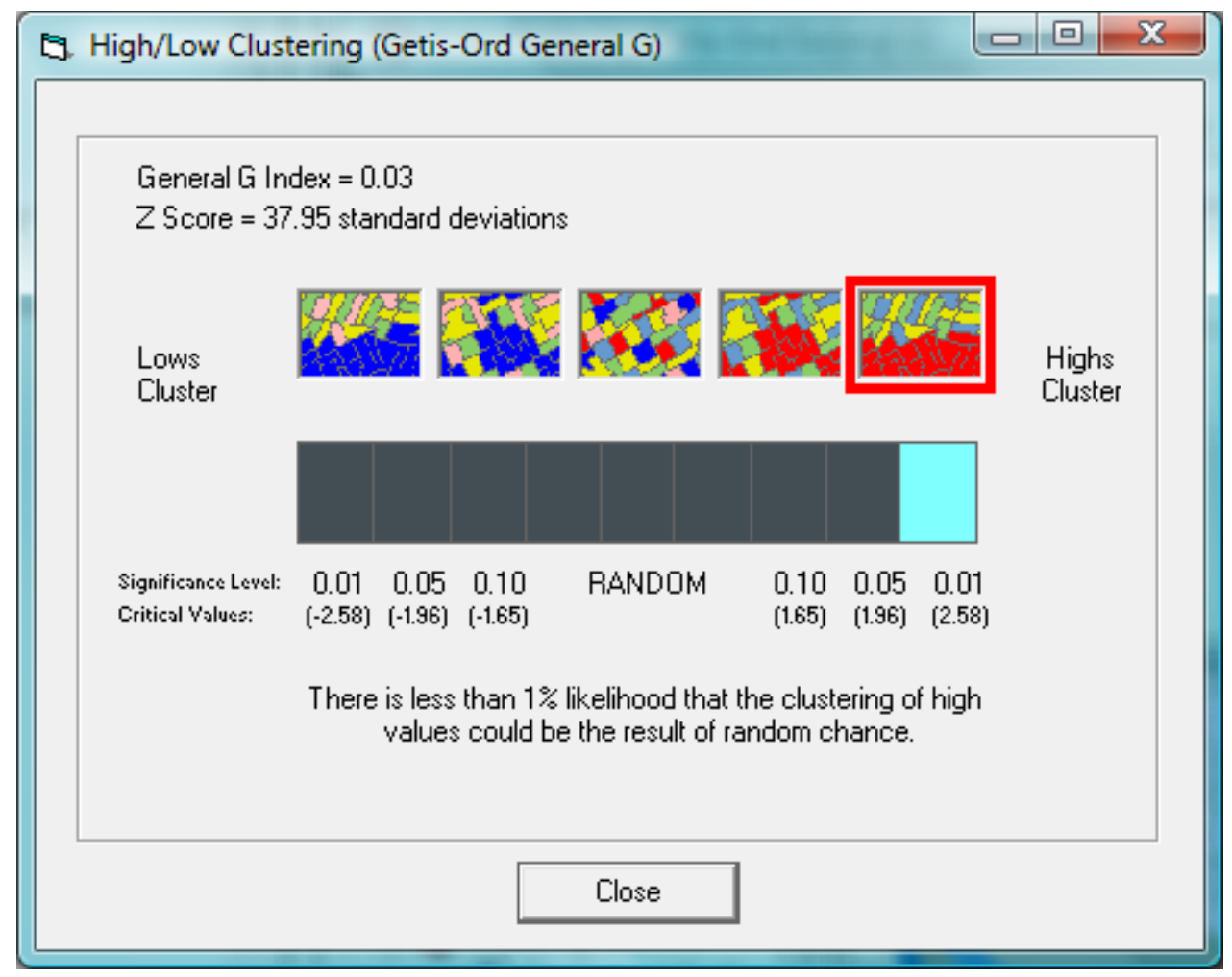

The Getis Ord G agrees with Moran’s I that the National Park simple designation description is highly correlated. 


\section{Chapter 5 Discussion and Conclusion}

A clustered pattern can been seen when an observation is taken of the distribution of every National Park unit in the continental United States in the years 1872 - 2007. The use of visual observations as well as making use of EDA and ESDA techniques to see if the distribution of National Park unit designations occurred because of chance or to discover correlative properties in designations was the goal of this study. Can looking at political, historical and geographical features open a door to this pattern? Yes, it can reveal plausible ideas on why this distribution is clustered. The use of local and global indicators of spatial autocorrelation found evidence that these National Park units are clustered via designations. No multivariate autocorrelation could be proved significant. Getis Ord G help cement the claim that the clustering was from similar designations. The autocorrelation via designation was checked at the county and at the park level across the entire continental United States and was clustered at both. Analyzing at both park and county levels aided in supporting that the created National Park unit and county database were sound and accurate.

There was not one overriding theme/variable that was found responsible for the clustered appearance of the National Park units. Historical and geographical variables were tested individually for a strong correlation and individually and one could not be found. While some of the variables such as streams/shoreline and federal lands created a high correlation, these figures are not significant. But when all five of the variables were compiled together a strong correlation existed. The findings suggest that designation and location of a National Park rely on multiple variables. This makes logical sense. If National Park units are set aside for the "benefit and enjoyment of the people” as stated by Theodore Roosevelt at the 1903 Yellowstone North 
entrance dedication speech, then one can presume that the location of these units should incorporate multiple characteristics that speak to the largest audience of Americans. For instance, most people do not visit Sleeping Bear Dunes National Park because it is only situated next to Lake Michigan. They visit the park because the park contains multiple variables that correspond to many Americans. This variable could be historical in nature or it may be spatial in nature such as, the distance to another similarly (Pictured Rocks) designated National Park units. This theory can also be used when one visits Yellowstone National Park. People do primarily visit Yellowstone National Park because of the geological features but many visitors utilize neighboring parks and enjoy the historical aspects of Yellowstone National park also, such as the Old Faithful Inn which is on the National Register of Historic Places. A location such as the Old Faithful Inn, which is placed on the National Register of Historic Places, designates that place as historical in nature in this analysis. Additionally, Yellowstone National Park is located near other similarly designated units such as the Grand Teton and the Bad Lands. A National Park unit that is located near other similarly designated locations may occurred because of geological reasons or it may have occurred because of managerial reasons such as trying to lessen the impact on one resource by giving additional options to visitors (Hanink \& Stutts, 2002). This was even true when explorers first visited Yellowstone and found multiple justifications for the importance of the resource. The explorer's letters back east spoke of the geological features as wondrous but their tales also spoke of the waterfalls and lakes of the park as well as the indigenous inhabitants. Pick a National Park unit and more than one variable will typically be found.

To draw a large population's consensus that a place is significant, a compromise must occur on what makes an area important enough for designation. Some people may find a 
connection to water, some citizens enjoy history, and others may only want to increase the economic conditions of their region and request a National Park unit designation (Great sand dunes national park and preserve act, 2000). There are some exceptions to this, for instance Flight 93 National Memorial. This tragic event occurred in this location because of chance.

The political aspect of the designation process appears to impacts the creation of additional parks, location and designation type. Knowing the political affiliation of the representation at the designation time, a confident prediction can be made on what type of park unit will be designated. This was not true for every political variation but many.

The data does show clusters and this may be partially explained by the large outliers that occurred with the political data. The political data showed that specific parties where more likely to designate specific designation types. For instance, the data showed that when there was Democratic control of the Presidency, Congress, and of both House and Senate state representatives, a National Park that was historical in nature was more likely to be designated. This finding is contrary to when Republicans are in control of the Presidency, Congress, and both state House and Senate representation where zero historical National Park units were created.

The political data also displayed a cluster in time. This can be seen in the time line graph and the two peaks in the graph. These clusters in time are partially caused by Democratic control. 167 or $47 \%$ of all National Park units were designated when the Presidency and Congress were in the Democratic majority. If there is a mix political control and there was a Democratic President and a Republican control of Congress only 20 or 5\% of the National Park units were designated. This supports clustering in time of either many designations or few 
designations. The amount of designations associated with political affiliation and when they are in the majority. Additionally, the passages of bills by Congress, such as the Antiquity Act (1916), cause specific designations to occur in higher numbers around the year of passage. This shows an example of partisanship in politics, but that data shows a 50 -50 split in the number of Presidential designations, thus the partisanship is from Congress.

Tobler's $1^{\text {st }}$ law of geography was supported by the findings. The clustering of similar designation proves Tobler's law. All National Park units are related but closer National Park units are more similar than National Park units that are farther away. If you visit the megalopolis you will have clusters of historically related National Park units, visit Virginia a clusters National Battlefield units, visit the four corners and a cluster of National Park designations.

\section{Limitations and need for future research}

This research was challenged by some limitations as well as by bias. Every researcher has constraints that may appear in their work. In this research the major limitation would be human error. Human error, if occurred, most likely occurred while creating the database or while creating the digitization of theme/variable location. Digitizations of the points were conducted at a minimum of 250,000 map scale. While this was an adequate scale for digitizing at a county level this accuracy could be improved by digitizing at a smaller map scale. The other human error limitation may have occurred when inputting records into the database. In both human error possibilities, every attempt was taken to ensure data quality but this limitation must be stated. 
There is a need for further research with this topic. This research has created a base to be built upon. Deeper research needs to be investigated on each of the variables as well as a more indebt history needs to be built for each individual National Park. Knowing what the history is behind each individual National Park unit may open other more relevant possibilities for designation as a National Park unit. Also, knowledge of all National Park units may provide additional ideas to be explored.

With additional research, a possible prediction model of some sort can be built to predict National Park designation. This research shows that an assumption can be made about political affiliation when the designation type is known. But, it was not the goal of this research to create a prediction model. With that stated, the foundation of creating a prediction model has been shown. If the data from the themes, which when accumulated accounted for an $81 \%$ correlation and the political data is combined may provide a suitable prediction model.

This research may prove useful for many disciplines. Additional research in the future may make use of this data in a variety of ways and may find these results useful. Political research, history, land management are just some of the possible future research. 
Works Cited

American Antiquities Act, 16 USC 431-433 (1906).

Anselin, L. (1999). Interactive techniques and exploratory spatial data analysis. In M. G. P. Longley, Geographical Information Systems: Principles, Techniques, Management and Application (pp. 251 - 264). New York: Wiley.

Anselin, L. (1996). The moran scatterplot as an esda tool to assess local instability in spatial association. In M. M. Fischer, H. J. Scholten, \& U. David, Spatial analytical perspectives on gis (pp. 111-125). Lodon: Taylor \& Francis.

Anslene, L., Dodson, R., \& Hudak, S. (1993). Linking gis and spatial data analysis in practice. Geographical Systems , 1, 3 - 23.

Bolstad, P. (2008). Gis fundamentals a first text on geographical information systems. White Bear Lake, MN: Eider Press.

Cartography Associates. (2005). The Yellowstone National Park via Northern Pacific Railway. Retrieved November 10, 2010, from David Rumsey Map Collection: http://www.davidrumsey.com/luna/servlet/detail/RUMSEY 8 1 24271 910059:Covers-to--The-YellowstoneNationa?qvq=q:Northern+Pacific+Yellowstone;lc:RUMSEY 8 1\&mi=1\&trs=13

Clark, K. C. (2003). Getting started with geographic information systems (Vol. 4). Upper Saddle River, New Jersey: Pearson Education, Inc.

Code of federal law, 62 FR 30234 (June 3, 1997).

Dilsaver, L. (1997). American's national park system: the critical documents. London, England: Rowman \& Littlefield.

Draffan, G. (1998). Taking back our lands: a history of railroad land grant reform. Retrieved 11 10, 2010, from Land grant: http://www.landgrant.org/takingback.pdf

Environmental Systems Research Institute. (No Date, n.d. n.d.). Glossary. Retrieved November 2, 2010, from ArcGIS Resource Center: http://resources.arcgis.com/glossary

Fehl, P. (2010). Green careers: law, government, and public saftey. New York: Infobase Publishing.

Fotheringham, A. (1992). Exploratory spatial data analysis and gis. Commentaries , 1,675 1,677 .

Great sand dunes national park and preserve act (Congressional Record October 24, 2000). 
Hanink, D. M., \& Stutts, M. (2002). Spatial demand for national battlefield parks. Annals of Tourism Research , 29 (3), 707-719.

Heritage Preservation Services. (No Date, n.d. n.d.). American Battlefields. Retrieved October 12, 2010, from Heritage Preservation Services: http://www.nps.gov/history/hps/abpp/abpp_p.htm

Johns, J. S. (1996, August 1). The role of the railroads in protecting, promoting, and selling yellowstone and yosemite national park. Retrieved November 11, 2010, from American Studies at the University of Virginia: http://xroads.virginia.edu/ MA96/RAILROAD/adverts1.html

Johnson, E. R. (1915). History of domestic and foreign commerce of the united states. Washington D.C.: Carnegie Institution of Washington.

Joiner, B. l., Ryan, B. F., \& Ryan, T. A. (2005). Minitab handbook updates for release 14 (5th ed.). Belmont, California: Brooks Cole - Thomson Learning .

Mackintosh, B. (2003, January 13). The national parks: a brief history. Retrieved November 1, 2010, from National Park Service E-Library: http://www.nps.gov/history/history/hisnps/NPShistory/briefhistory.htm

Mercer, L. J. (1982). Railroads and land grant policy: a study in government intervention. New York: Academic Press.

Merriam-Webster's. (2004). Merriam-webster's collegiate dictionary. Springfield: Merriam Webster Incorporated.

Moore, D. S., McCabe, G. P., \& Craig, B. A. (2009). Introduction to the practice of statistics. New York: W.H. Freeman and Company.

National Archives and Records Administration. (2010). Code of federal regulation protection of the environment (Vol. 40). Washington D.C.: U.S. Government Printing Office.

National Park Service. (2000, March 28). Designation of national park system units. Retrieved December 1, 2010, from National Park Service Legacy: http://www.nps.gov/legacy/nomenclature.html

National Park Service. (2003). Special resource study: great falls historic district. Philadelphia, PA: National Park Service.

Oh, K., \& Jeong, S. (2007). Assessing the spatial distribution of urban parks using gis. Land and Urban Planning , 82, 25 - 32.

Omnibus Appropriations Act of 2001, Pub. L. No. 107-59, 115 Stat. 407. 
Omnibus Appropriations Act of 2009, Pub. L. No. 111 Stat. 9.

Organic Act of 1916, 16 U.S.C. § 1, 2,3, and 4 (1970)..

Palmer, T. (1993). The wild and scenic rivers of america. Washington D.C.: Island Press.

Public Law 89-665; , 16 U.S.C. 470 et seq.

Reed, D., \& Burkhart, H. (1985). Spatial autocorrelation of individual tree characteristics in loblolly pine stands. Forest Science , 31 (3), 575 - 587.

Rydell, K. L., \& Culpin, M. S. (2006). Managing the "matchless wonders": a history of administrative development in yellowstone national park, 1872 - 1965. Yellowstone National Park, Wyoming: National Park Service, Yellowstone Center for Resources.

Sellers, R. (1997). Preserving nature in the national parks. Ann Arbor, MI: Yale University Press.

Sheehan, K., \& Welsh, S. (2009). An interpolation method for stream habitat assessments. Journal of Fisheries Management , 29, 1 - 9.

Shelton, J. (2007). Invisible Men: Buffalo Soldiers of the Sierra Nevadas. Sequoia National Park: National Park Service.

Stynes, D. (2006). National park spending and payroll impacts. Retrieved 9 10, 2010, from National Park Service Social Science: www1.nature.nps.gov/socialscience/pdf/Econ_Impact_FY05.pdf

The Yellowstone Act of 1872, 16 U.S.C. §21 (1872)..

Thwaites, R. G. (1905). The original journals of the lewis and clark expedition 6. New York: Dodd, Mead.

Tobler, W. (1970). A computer movie simulating urban growth in the detroit region. Economic Geography , 46 (2), 234-240.

Tufte, E. R. (1978). Political control of the economy. Princeton, New Jersey: Princeton University Press.

Tukey, J. W. (1977). Exploratory data analysis. Applied Psychological Measurement , 151 - 155.

United States. (2003, March 5). National Atlas. Retrieved 10 10, 2010, from National Atlas of the United States: www.nationalatlas.gov

Unknown. (2010, December 6). Congressman Bill Pascrell. Retrieved December 6, 2010, from Congressman Bill Pascrell: http://pascrell.house.gov/index.shtml 
Unknown. (2009). Lake McDonald Lodge additional photos. Retrieved November 10, 2010, from National Park Lodge Architecture: http://nplas.org/mcdonald2.html

Waldron, S. (2008). National park service 2008 director's report. Washington D.C.: U.S. Department of the Interior.

Wheeler, O. D. (1896). The late james gemmell. Helena, Montana: State Publishing Co.

Yard, R. S. (1922, August 1). The people and the national parks. The Survey, pp. 547 - 553. 